\title{
22. PETROGRAPHY AND CHEMICAL COMPOSITION OF THE LAVA FLOWS FROM THE EMPEROR SEAMOUNTS, DSDP LEG 55
}

\author{
G.P. Avdeiko, S.A. Khubunaja, and J.V. Vande-Kirkov, Institute of Volcanology, Far East Science Center, \\ USSR Academy of Sciences, Petropavlovsk-Kamchatsky, USSR
}

\section{INTRODUCTION}

During DSDP Leg 55, volcanic rocks were recovered at Sites 430, 432, and 433, on Ōjin, Nintoku, and Suiko seamounts, respectively, in the Emperor Seamount chain. Of the five lava flows recovered at Hole 430A, the upper four flows are typical hawaiites and the lowest flow is tholeiite. Three lava flows of alkalic basalts recovered at Hole $432 \mathrm{~A}$ on Nintoku Seamount are petrographically and chemically similar to the analogous rocks from the Hawaiian Islands. Ninety-six cooling units, from 163 to 550 meters sub-bottom, were sampled at the re-entry Hole 433C. Most of them are lava flows and others are secondary thin flows or flow lobes from fissures of basic flows. The three uppermost flows are alkalic basalts. Eight individual cooling units of picritebasalts (Flow Units $4 \mathrm{~A}-4 \mathrm{H}$ ) occur below them. The underlying sequence of flows is composed almost entirely of tholeiites; only four flows are transitional toward alkalic basalts, and one of them is picrite-basalt.

In spite of the nearly complete absence of sedimentary and pyroclastic interbeds between the flows, good recovery permitted us to distinguish boundaries of cooling units and determine their thicknesses. We calculated the thicknesses of tholeiitic and transitional basalt flows in the flow sequence of Hole $433 \mathrm{C}$ assuming that the flows fill all void space proportionally to the recovery in each flow. Most cooling units range in thickness from 0 to 2 meters (Figure 1A). This is the interval defining not only primary lava flows, but also secondary flows or flow lobes. A minimum in the interval from 1.25 to 1.5 meters (Figure 1B) apparently is a boundary between lava flows and flow lobes. As a whole, this agrees with data obtained in the Hawaiian Islands, where thickness of the tholeiitic flows is commonly not less than 1 meter (Macdonald and Abbott, 1970), although very thin flows can be found occasionally, for instance, tholeiitic flows 0.3 to 1.3 meters thick in the flow sequence of Waikolu Valley, Molokai Island (Beeson, 1976).

This study is undertaken to determine petrologic and chemical heterogeneities caused by crystallization conditions and alteration. Figure 2 illustrates the position of 10 flows under study. Forty-nine samples from top to bottom of these flows were studied in thin sections. Grain sizes of the groundmass minerals were measured. Optical determinations of plagioclase composition were made according to Vande-Kirkov's (1974) method using the Fedorov universal stage. The whole-rock composition of major elements was determined using the classical wet method (except for $\mathrm{Na}_{2} \mathrm{O}$ and $\mathrm{K}_{2} \mathrm{O}$ ) in the Cen-

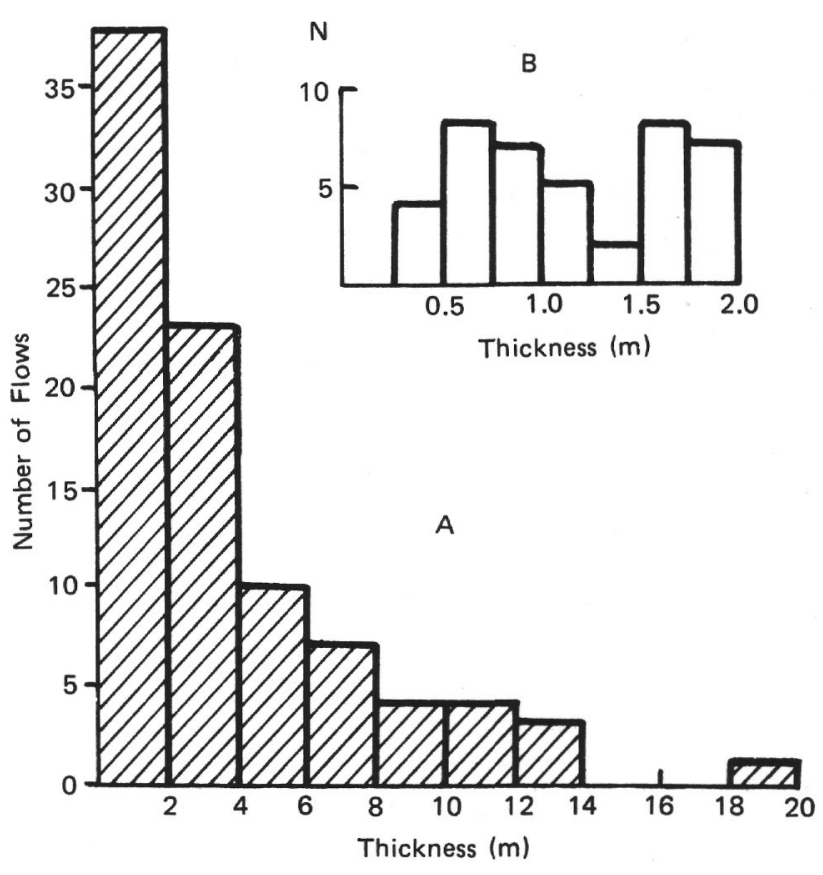

Figure 1. Histograms showing occurrence of tholeitic basalt flows in Hole 433C: (A) for all flows; (B) for flows with thickness from 0 to 2 meters.

tral Chemical Laboratory of the Institute of Volcanology, FESC, USSR Academy of Sciences. Electron microprobe analyses of some plagioclase and olivine phenocrysts were made at the Institute of Geochemistry and Analytical Chemistry, USSR Academy of Sciences. $\mathrm{X}$-ray diffraction methods were used for identification of clays after glass and olivine.

\section{FLOW UNIT 3, HOLE 432A}

The flow of alkalic basalt-hawaiite is overlaid by a red soil horizon. The flow bottom was not reached. The total flow recovery in the cored interval $(55-74 \mathrm{~m}$, Cores 3,4 , and 5) was 12.4 meters. Since the recovery was practically complete in Cores 4 and $5(96.9 \%$ and $90 \%$, respectively, we consider the flow recovery in Core 3 to be not much worse, and the low recovery in Core $3(36.2 \%)$ might be accounted for by washing out of the soil horizon. Thus, the thickness of the penetrated part of this flow is not 19 but 15 to 16 meters.

The flow is massive, with some vesicles near the top and horizontal lines of elongated vesicles in the flow interior (Core 4, Section 3, 67-135 cm). Seven samples throughout the flow were studied (Figures 3, 4). 


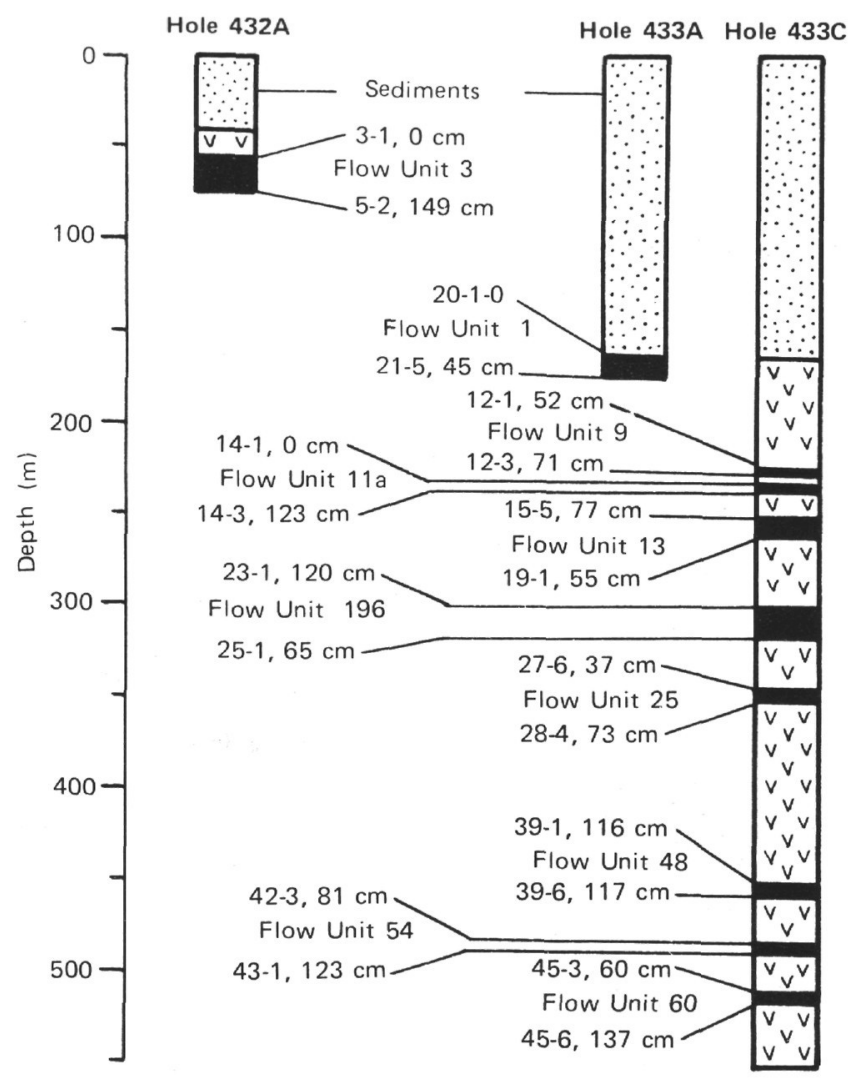

Figure 2. Index diagram showing positions of flows studied in this paper.

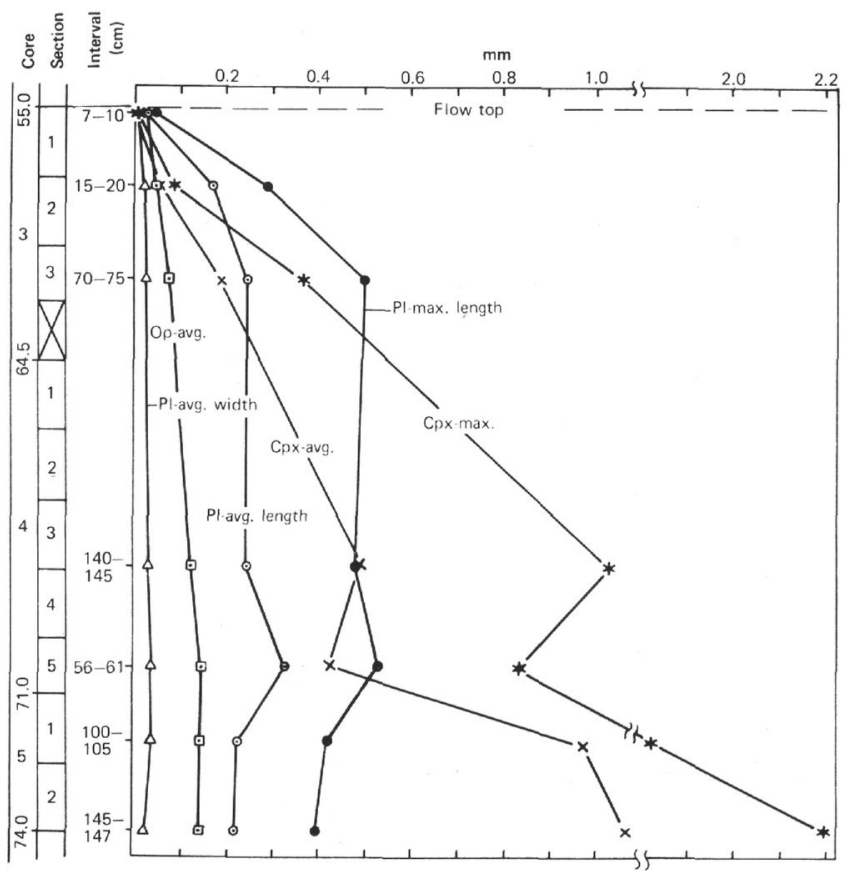

Figure 3. Size variation diagram of plagioclase, pyroxene, and opaque grains in groundmass of Flow 3, Hole $432 \mathrm{~A}$.

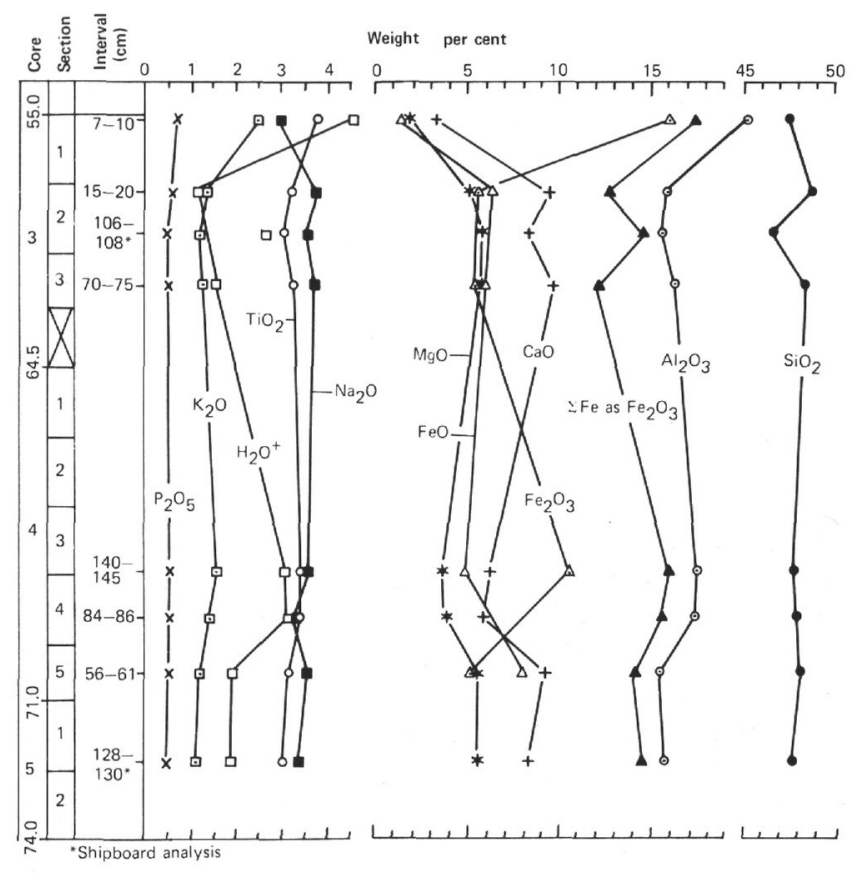

Figure 4. Variations of bulk chemistry throughout Flow 3, Hole $432 \mathrm{~A}$.

\section{Petrography}

Sparsely olivine phyric basalt in the least altered flow interior consists of rare (up to 2 or $3 \%$ ) olivine phenocrysts and microphenocrysts, single plagioclase phenocrysts, and groundmass with different fraction crystallized and various grain sizes, depending on sample location in the flow. Mineral sizes are large and fraction crystallized is higher in the flow interior.

Olivine phenocrysts and microphenocrysts (0.5-3 $\mathrm{mm})$ are usually altered to clays with iddingsite rims which are thicker in oxidized parts of the flow, up to full alteration to iddingsite. Fresh cores of olivine phenocrysts are present in the flow interior (Core 3, Sections 2 and 3). The groundmass is composed of plagioclase $\left(A n_{60-30}\right)$ microlites, grains of clinopyroxene, olivine altered to clays and iddingsite, opaque minerals, apatite, interstitial feldspar, and clays after glass. The quantitative mineral composition of the groundmass and grain sizes of plagioclase and clinopyroxene are shown in Table 1 and Figure 3, respectively. It is difficult to separate plagioclase microlites from interstitial feldspar, so they are shown together as plagioclase (Table 1). Interstitial feldspar is characterized by low doublerefraction and refractive index close to 1.54. Analogous feldspar is typical of the Hawaiian alkalic rocks (Macdonald and Katsura, 1964).

Clinopyroxene is represented by two minerals: augite and titanaugite. Titanaugite has a higher double-refraction, clear pleochroism, sand-glass texture, and twins. It is interesting that the length of plagioclase microlites increases from 0.05 to $0.5 \mathrm{~mm}$ only from the flow top to a depth of about 4 meters (Figure 3). At greater depths, the length of plagioclase microlites does not increase, 
TABLE 1

Modal Composition (vol. \%) of the Groundmass of Flow Unit 3, Hole 432A

\begin{tabular}{l|l|r|r|r|r|r}
\hline $\begin{array}{l}\text { Sampled } \\
\text { Interval }\end{array}$ & P1 & Cpx & Ol & Op & Gl & Ap \\
\hline $3-1,7-10 \mathrm{~cm}$ & 52 & $<1$ & 10 & 12 & 25 & $<1$ \\
$3-2,15-20$ & 64 & 10 & 5 & 12 & 8 & 1 \\
$3-3,70-75$ & 63 & 14 & 6 & 9 & 7 & 1 \\
$4-3,140-145$ & 60 & 17 & 8 & 9 & 5 & 1 \\
$4-5,56-61$ & 63 & 12 & 6 & 10 & 8 & 1 \\
$5-1,100-105$ & 60 & 17 & 7 & 10 & 5 & 1 \\
$5-2,145-147$ & 57 & 20 & 8 & 9 & 5 & 1 \\
\hline
\end{tabular}

Note: $\mathrm{Pl}$ - plagioclase + some interstitial feldspar; Cpx - clinopyroxene (titanaugite + some augite); $\mathrm{Ol}$ - olivine altered to clays and iddingsite; $\mathrm{Op}$ opaque minerals; Gl - glass altered to clays; Ap apatite.

but even decreases. The increase of the maximum length of plagioclase microlites up to $0.52 \mathrm{~mm}$ was found in Core 4, Section 5, 56-61 cm. In contrast to plagioclase, grain sizes of clinopyroxene (titanaugite) increase gradually from zero in the flow top to $1.03 \mathrm{~mm}$ in Core 4, Section 3, $140-145 \mathrm{~cm}$, then they decrease to $0.51 \mathrm{~mm}$ in Core 4, Section 5, 56-61 $\mathrm{cm}$. They increase again up to $2.2 \mathrm{~mm}$ in Core 5, Section 2, 145-147 cm (Figure 3). The groundmass varies in texture throughout the flow, in accordance with changes of mineral sizes and their volume contents. In the flow top, the groundmass is vitrophyric; some 1.7 meters lower it is already intergranular; when the size of titanaugite grains increases, the groundmass texture becomes sub-ophitic and ophitic.

We suppose that the decrease of titanaugite size in Core 4, Section 5, 56-61 cm (Figure 3) marks the boundary between two portions of the composite flow. The upper portion overlaid the earlier one when the flow was still hot, and that is why the boundary is not distinct. Macdonald (1972) described the composite lava flows at Haleakala Volcano, Hawaii, where portions of the same flow have different compositions. In our case, they have the same composition. The decrease of titanaugite sizes at the boundary between two portions of this flow corresponds to the increase of plagioclase sizes. This is probably connected with the greater rate of plagioclase crystallization at larger undercooling. We shall dwell upon this problem in detail in the Discussion section.

\section{Chemistry}

Table 2 presents the results of the whole-rock chemical composition, and Figure 4 shows variations in the concentrations of major elements, calculated for dry weight, from top to bottom of the flow. High $\mathrm{Fe}_{2} \mathrm{O}_{3}$ and respectively low $\mathrm{FeO}$ contents are most characteristic indexes for oxidized zones. $\mathrm{Fe}_{2} \mathrm{O}_{3} / \mathrm{FeO}$ ratio increases up to 12.0 in the flow top, and up to 2.2 in the fractured oxidized zone near the flow portion boundary, while it is between 0.6 and 0.9 in the freshest parts. Besides, oxidized zones are enriched in total $\mathrm{Fe}$ as $\mathrm{Fe}_{2} \mathrm{O}_{3}$, in $\mathrm{Al}_{2} \mathrm{O}_{3}$, $\mathrm{K}_{2} \mathrm{O}$, and $\mathrm{H}_{2} \mathrm{O}^{+}$contents, and are impoverished in $\mathrm{MgO}$ and $\mathrm{CaO}$ (Figure 4). Alteration of the same type to even a greater degree is common for lateritic weathering.
We have not found distinct chemical variations within the least altered flow interior. As a whole, the chemical composition of this flow is close to the average hawaiite from the Hawaiian Islands (Macdonald and Katsura, 1964; Macdonald, 1968). Olivine content in norm reaches some 10 per cent in the freshest parts (Table 2). If there is olivine, quartz is absent; and vice-versa.

\section{FLOW UNIT 1, HOLE 433A}

This flow of alkalic basalt is overlaid by reef carbonate sand and limestone calcarenite. The bottom of the flow was not reached. Proceeding from the cored interval, the flow thickness is more than 11.5 meters and the core recovery is 8.5 meters.

\section{Petrography}

Massive basalt of this flow unit consists of fresh plagioclase phenocrysts (6 to $10 \%$ ), olivine phenocrysts altered to clays and iddingsite, single grains of clinopyroxene, and groundmass. The groundmass is composed of plagioclase microlites with some interstitial feldspar, grains of pyroxene, opaque mineral, rare apatite, and some clays (smectite) after glass.

Tabular plagioclase phenocrysts up to 5 to $7 \mathrm{~mm}$ long are zoned from $A n_{90}$ in cores to $A n_{52}$ in margins with low and moderate ordering. They become noticeably more abundant from the flow top to the interior (from 6 to $10 \%$, respectively). The chemical composition of plagioclase phenocrysts, determined with electron microprobe, is presented in Table 3 . It corresponds to a composition of $\mathrm{An}_{69.1-70.7}, \mathrm{Ab}_{28.4-29.8}, \mathrm{Or}_{0.9-1.1}$. Plagioclase is fresh, except for the flow top, where there is slight alteration of phenocryst cores in cleavages; more acid plagioclase margins are not altered. Sizes of olivine phenocrysts, altered completely to clays and iddingsite, increase down the unit, from $0.5-1.2 \mathrm{~mm}$ in the top to 1.5-2.5 $\mathrm{mm}$ at 9 meters below the top (Core 21, Section $4,138-140 \mathrm{~cm})$. Olivine increases in the same direction from 2 to 5 per cent.

Quantitative mineral compositions and sizes of groundmass minerals also change from the flow top to the interior. If at the top (Core 20, Section 1, 84-85 cm) the contents of clays after glass are 25 to 30 per cent, plagioclase microlites 55 to 60 per cent, clinopyroxene 5 per cent, opaque minerals 7 per cent, and olivine 3 per cent (calculated to $100 \%$ of groundmass), then 1 to $2 \mathrm{~cm}$ lower the contents of clays after glass decrease to 10 to 15 per cent at the expense of the clinopyroxene content and to a lesser degree that of plagioclase. With the growth of groundmass crystal size toward the flow interior, the contents of clays after glass decrease to 5 per cent and clinopyroxene content increases to 20 to 25 per cent.

Figure 5 shows sizes of groundmass, plagioclase, clinopyroxene, and opaque mineral. Sample 20-1, 83-89 cm demonstrates the sharp increase of grain sizes in a short interval: the length of plagioclase microlites almost doubles, and the length of pyroxene grains increases 1.5 times (see Figure 5) in the interval between 85 and 87 $\mathrm{cm}$. Sharp differences in groundmass mineral sizes are typical for boundaries between the chilling crust and the 
TABLE 2

Whole-Rock Chemical Composition of Lava Units from Emperor Seamounts

\begin{tabular}{|c|c|c|c|c|c|c|c|c|c|c|c|c|c|c|c|c|c|c|c|c|}
\hline \multirow[b]{2}{*}{ Sample $^{\mathrm{a}}$} & \multicolumn{6}{|c|}{ Hole 433C, Flow Unit 25} & \multicolumn{5}{|c|}{ Hole 433C, Flow Unit 48} & \multicolumn{4}{|c|}{ Hole $433 \mathrm{C}$, Flow Unit 54} & \multicolumn{5}{|c|}{ Hole 433C, Flow Unit 60} \\
\hline & 52 & 53 & 54 & 55 & 56 & 57 & 73 & 74 & 75 & 76 & 77 & 81 & 82 & 83 & 84 & 89 & 90 & 91 & 92 & 93 \\
\hline $\mathrm{SiO}_{2}$ & 43.30 & 46.30 & 47.68 & 48.70 & 48.62 & 48.30 & 43.00 & 43.72 & 45.28 & 45.68 & 46.62 & 44.46 & 47.96 & 47.96 & 46.44 & 46.64 & 47.22 & 48.14 & 47.50 & 47.70 \\
\hline $\mathrm{TiO}_{2}$ & & 2.75 & 2.67 & 2.50 & 2.42 & 2.37 & $\begin{array}{r}4.03 \\
1.93\end{array}$ & 2.30 & $\begin{array}{r}4.26 \\
2.10\end{array}$ & 2.12 & $\begin{array}{r}40.02 \\
2.10\end{array}$ & 2.22 & 2.12 & $\begin{array}{rl}2.09 & 1.90 \\
4\end{array}$ & $\begin{aligned} \begin{array}{r}40.44 \\
2.27\end{array} & -27\end{aligned}$ & $\begin{array}{r}4.064 \\
2.38\end{array}$ & 2.25 & $\begin{array}{r}4.34 \\
2.38\end{array}$ & 2.27 & 2.19 \\
\hline $\mathrm{Al}_{2} \mathrm{O}_{3}$ & 14.22 & 15.61 & 15.93 & 14.21 & 14.43 & 14.19 & 12.49 & 15.25 & 13.03 & 13.49 & 13.41 & 14.75 & 15.90 & 16.12 & 16.54 & 15.03 & 14.84 & 14.95 & 15.59 & 15.53 \\
\hline $\mathrm{Fe}_{2}^{2} \mathrm{O}_{3}$ & 12.27 & 7.57 & 3.77 & 5.00 & 4.62 & 5.75 & 10.14 & 8.76 & 4.67 & 4.24 & 3.76 & 9.49 & 4.55 & 4.04 & 8.18 & 9.12 & 7.60 & 4.20 & 4.03 & 4.94 \\
\hline Feó & 1.98 & 4.20 & 7.21 & 7.64 & 6.84 & 5.66 & 4.05 & 3.94 & 7.82 & 8.13 & 8.47 & 4.41 & 6.97 & 7.36 & 3 & 4.38 & 6.05 & 4 & 7.20 & 6.11 \\
\hline $\mathrm{MnO}$ & 0.08 & 0.13 & 0.12 & 0.15 & 0.15 & 0.15 & 0.13 & 0.15 & 0.16 & 0.22 & 0.21 & 0.08 & 0.12 & 0.12 & 2 & 0.12 & 0.15 & 9 & 0.19 & 0.19 \\
\hline $\begin{array}{l}\mathrm{MgO} \\
\mathrm{CaO}\end{array}$ & 7.28 & 6.80 & 8.09 & 7.14 & 7.34 & 8.79 & 13.02 & 11.13 & 12.36 & 11.72 & 11.30 & 8.14 & 6.80 & 6.95 & 6.80 & 7.54 & 6.20 & 6.37 & 7.25 & 7.59 \\
\hline $\begin{array}{l}\mathrm{CaO} \\
\mathrm{Na} 2 \mathrm{O}\end{array}$ & $\begin{array}{l}2.60 \\
2.07\end{array}$ & $\begin{array}{l}7.80 \\
2.80\end{array}$ & $\begin{array}{l}9.06 \\
2.70\end{array}$ & $\begin{array}{l}9.73 \\
2.63\end{array}$ & $\begin{array}{l}9.65 \\
270\end{array}$ & $\begin{array}{l}7.87 \\
2.63\end{array}$ & $\begin{array}{l}1.83 \\
2.39\end{array}$ & 3.73 & 7.20 & 8.46 & 8.78 & 6.54 & 10.48 & 10.83 & 7.78 & 8.48 & 9.93 & 11.04 & 10.41 & 9.70 \\
\hline $\mathrm{K}_{2} \mathrm{O}$ & $\begin{array}{l}2.01 \\
2.27\end{array}$ & $\begin{array}{l}2.80 \\
1.48\end{array}$ & 0.52 & $\begin{array}{l}2.63 \\
0.29\end{array}$ & $\begin{array}{l}2.70 \\
0.90\end{array}$ & $\begin{array}{l}2.63 \\
116\end{array}$ & $\begin{array}{r}2.39 \\
1.29\end{array}$ & 2.59 & $\begin{array}{l}2.19 \\
0.26\end{array}$ & 1.91 & 1.93 & 2.77 & $\begin{array}{l}2.48 \\
0.40\end{array}$ & $\begin{array}{l}2.36 \\
0.20\end{array}$ & $\begin{array}{l}2.96 \\
0.78\end{array}$ & $\begin{array}{l}2.75 \\
0.43 \\
\end{array}$ & $\begin{array}{l}2.50 \\
0.96\end{array}$ & $\begin{array}{l}2.50 \\
0.43\end{array}$ & 2.45 & 2.61 \\
\hline $\mathrm{H}_{2} \mathrm{O}^{-}$ & 5.07 & 2.06 & 0.88 & 0.67 & 0.91 & 1.44 & $\begin{array}{l}1.29 \\
5.20\end{array}$ & $\begin{array}{l}0.13 \\
4.14\end{array}$ & $\begin{array}{l}0.26 \\
2.34\end{array}$ & $\begin{array}{l}0.38 \\
2.32\end{array}$ & $\begin{array}{l}0.31 \\
0.98\end{array}$ & $\begin{array}{l}1.20 \\
2.18\end{array}$ & $\begin{array}{l}0.40 \\
0.60\end{array}$ & 0.20 & $\begin{array}{l}0.18 \\
1.36\end{array}$ & $\begin{array}{l}0.43 \\
1.16\end{array}$ & $\begin{array}{l}0.96 \\
0.50\end{array}$ & $\begin{array}{l}0.43 \\
0.50\end{array}$ & 0.78 & $\begin{array}{l}0.48 \\
0.89\end{array}$ \\
\hline $\mathrm{H}_{2} \mathrm{O}^{+}$ & & 226 & & 0.77 & 0.80 & 1.32 & 4.04 & 3.22 & 2.21 & $\begin{array}{l}2.32 \\
1.46\end{array}$ & & 3.04 & 1.27 & 1.11 & 2.5 & $\begin{array}{l}1.10 \\
1.51\end{array}$ & 1.73 & 1.00 & & 1.42 \\
\hline $\mathrm{P}_{2} \mathrm{O}_{5}$ & 0.07 & 0.22 & 0.27 & 0.26 & 0.27 & 0.27 & 0.16 & 0.16 & 0.21 & $\begin{array}{l}1.23 \\
0.23 \\
\end{array}$ & 0.21 & 0.27 & $\begin{array}{l}1.21 \\
0.24\end{array}$ & 0.22 & 0.24 & 0.25 & 0.25 & 0.22 & 0.21 & 0.21 \\
\hline \multirow[t]{2}{*}{ Total } & 99.31 & 99.98 & 99.74 & 99.69 & 99.65 & 99.90 & 99.67 & 99.82 & 99.83 & 100.36 & 100.42 & 99.55 & 99.89 & 99.76 & 100.22 & 99.79 & 100.18 & 99.96 & 99.38 & 99.56 \\
\hline & \multicolumn{20}{|c|}{ CIPW Norms } \\
\hline Q & 7.33 & 0.72 & - & 3.42 & - & 1.80 & 1.26 & 1.92 & - & - & - & 0.60 & 1.80 & 1.74 & 1.38 & 3.06 & 3.48 & 1.32 & 1.02 & 1.68 \\
\hline & 15.03 & 8.90 & 3.3 & 1.67 & 5.57 & 7.23 & & 4.45 & 1.67 & 2.23 & 1.67 & & & 1.11 & & & & & & 78 \\
\hline 3 & 19.92 & 24.64 & 23.59 & 22.54 & 23.59 & 23.07 & 22.54 & 23.59 & 19.40 & 16.78 & 16.78 & 24.64 & 21.50 & 20.45 & 1 & 24.12 & 21.50 & 21.50 & 21.50 & 22.54 \\
\hline $\begin{array}{l}\text { an } \\
\text { ne }\end{array}$ & 13.63 & 26.98 & 30.04 & 26.22 & 24.75 & 23.92 & 9.18 & 19.19 & 26.14 & 28.09 & 27.81 & 25.87 & 31.71 & 33.38 & 30.32 & 28.37 & 27.26 & 28.65 & 31.43 & 30.32 \\
\hline & - & 5.34 & 5.81 & 8.59 & 9.2 & 5.92 & $=$ & - & 3.95 & 5.57 & 6.2 & 2.79 & 8.1 & 8.1 & & 5.4 & & 10.45 & 8.2 & 7.20 \\
\hline en & - & 4.62 & & & & 4. & $=$ & $\overline{-}$ & 2.9 & & 4.3 & 2.41 & & 5.42 & 3.31 & 4.71 & & & & 5.42 \\
\hline fs & 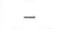 & & & 1.98 & 1.85 & 0.26 & & - & 0.66 & & 1.45 & & 1.98 & 2.11 & & & & & & 1.06 \\
\hline$\}$ en & 20.48 & 13.05 & 14. & 12.15 & 11.14 & 17.57 & 35.84 & 30.01 & 20.8 & 18. & 20.3 & 19.07 & 11.74 & 12.15 & 14.25 & 14.56 & & & 12.95 & 13.95 \\
\hline & - & - & & 4.09 & & 0.92 & - & - & 4. & 5. & 6.7 & - & 3.96 & 4.88 & - & - & 0.66 & 4.62 & 4.62 & 2.90 \\
\hline fo & - & - & 1.55 & - & 0.56 & - & - & - & 5. & & 3. & - & - & - & - & - & - & - & - & - \\
\hline$\underset{m b}{\mathrm{fa}}$ & - & - & 0.41 & - & 0.20 & - & $=$ & - & 1.63 & 1.63 & 1.0 & - & - & - & $\ldots$ & - & - & $H_{-}$ & - & - \\
\hline $\begin{array}{l}\text { mt } \\
\text { il }\end{array}$ & $\overline{486}$ & $\begin{array}{l}6.02 \\
5.46\end{array}$ & 5.56 & 7.41 & 6.95 & 8.57 & 8.57 & 6.45 & 7.1 & 6.25 & 5.5 & 8.57 & 6.71 & 6.02 & 7.64 & 7.87 & 11.34 & 6.25 & 6.25 & 7.41 \\
\hline 11 & 4.86 & $\begin{array}{l}5.46 \\
0.67\end{array}$ & $\begin{array}{l}5.16 \\
0.67\end{array}$ & $\begin{array}{l}4.86 \\
0.67\end{array}$ & $\begin{array}{l}4.70 \\
0.67\end{array}$ & $\begin{array}{l}4.70 \\
0.67\end{array}$ & $\begin{array}{l}4.10 \\
0.34\end{array}$ & $\begin{array}{l}4.70 \\
0.34\end{array}$ & $\begin{array}{l}4.25 \\
0.67\end{array}$ & $\begin{array}{l}4.1 \\
0.6\end{array}$ & $\begin{array}{l}4.10 \\
0.67\end{array}$ & $\begin{array}{l}4.4 \\
0.6\end{array}$ & $\begin{array}{l}4.10 \\
0.67\end{array}$ & $\begin{array}{l}4.10 \\
0.67\end{array}$ & 0.6 & $\begin{array}{l}4.70 \\
0.67\end{array}$ & $\begin{array}{l}4.40 \\
0.67\end{array}$ & $\begin{array}{l}4.55 \\
0.67\end{array}$ & $\begin{array}{l}4.40 \\
0.67\end{array}$ & $\begin{array}{l}4.25 \\
0.67\end{array}$ \\
\hline hn & 13.8 & 3.83 & - & - & - & - & 5.67 & 4.63 & 0.0 & - & - & 4.15 & - & - & 3.19 & 3.99 & - & - & - & - \\
\hline ru & 0.16 & - & - & - & - & - & . & - & - & - & 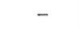 & - & 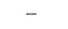 & - & - & - & - & - & - & 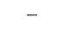 \\
\hline & 4.49 & - & - & - & - & - & 4.49 & 4.08 & - & - & - & - & - & - & - & - & - & - & - & - \\
\hline
\end{tabular}

a 13: Sample 3-1, 7-10 cm; 14: 3-2, 15-20 cm; 15: 3-3, 70-75 cm;16: 4-3,140-145 cm; 17: 4-5, 56-61 cm; 18: 5-1, 100-105 cm; 30: $12-1,75-80 \mathrm{~cm} ; 31: 12-2,32-37 \mathrm{~cm} ; 32: 12-2,136-141 \mathrm{~cm} ; 33: 12-3$, $30-35 \mathrm{~cm} ; 35: 14-1,2-7 \mathrm{~cm} ; 36: 141,33-38 \mathrm{~cm} ; 37: 14-2,115-120 \mathrm{~cm} ; 41: 15-5,82-87 \mathrm{~cm} ; 42: 16-1,32-38 \mathrm{~cm} ; 43: 17-1,64-69 \mathrm{~cm} ; 44: 19-1,48-54 \mathrm{~cm} ; 47: 23-2,12-17 \mathrm{~cm} ; 48: 24-7,108-114 \mathrm{~cm} ; 52:$ $27-6,38-43 \mathrm{~cm} ; 53: 27-6,135-140 \mathrm{~cm} ; 54: 28-1,42-47 \mathrm{~cm} ; 55: 28-2,66-73 \mathrm{~cm} ; 56: 28-3,136-142 \mathrm{~cm} ; 57: 28-4,30-37 \mathrm{~cm} ; 73: 39-7,119-122 \mathrm{~cm} ; 74: 39-2,35-40 \mathrm{~cm} ; 75: 39-3,88-93 \mathrm{~cm} ; 76: 39-5,2-8$ $97-102 \mathrm{~cm}$.

flow interior. We therefore consider the flow top to be almost non-eroded, except for the chilling crust. The plagioclase laths increase up to $1.26-1.28 \mathrm{~mm}$ at 4 to 4.5 meters from top, and downward they remain nearly the same, whereas the clinopyroxene sizes increase in almost linear progression with distance from the flow top (see Figure 5). In comparison with Flow 3, Hole 432A, this flow differs not only in its porphyritic texture but in the relationship of sizes of groundmass plagioclase and clinopyroxene. This is clearly evident when comparing Figures 3 and 5. If in Flow 3 the limited length of the groundmass plagioclase is $0.52 \mathrm{~mm}$, then in this flow the plagioclase length reaches $1.4 \mathrm{~mm}$. The groundmass clinopyroxene sizes of these flows are nearly identical at the same depths.

\section{Chemistry}

Only the shipboard analyses made by Pierre Cambon are used for characterizing the whole-rock chemical composition of this flow (Figure 6). Noticeable variations of compositions throughout the flow are absent, because the uppermost part of the flow (chilling crust) is eroded and the bottom was not reached. Small differences between $\mathrm{MgO}, \mathrm{CaO}, \mathrm{Al}_{2} \mathrm{O}_{3}$, and $\mathrm{Na}_{2} \mathrm{O}$ contents in two samples from Core 20, Section 2 (see Figure 6) are perhaps connected with the presence of a sandstone horizon or vein which is not the boundary of flows, since mineral sizes of the groundmass remain essentially unchanged and oxidized zones are absent.

\section{FLOW UNIT 9, HOLE 433C}

Tholeiitic basalt of this flow is about 3.5 meters thick; the recovered core length is 2.9 meters. The oxi- dized top of the flow is vesicular (vesicles up to $25 \%$ ) and the bottom is both less oxidized and vesicular (10$12 \%$ ); the content of vesicles in the flow interior is about 5 to 7 per cent. Five intervals were sampled for thin sections and chemical study.

\section{Petrography}

The main phenocryst mineral $(2-5 \%)$ is olivine 0.3 to $0.4 \mathrm{~mm}$ in size. It is usually altered to clays with iddingsite rims. There are some fresh cores in the flow interior. Olivine phenocrysts $(0.3-0.5 \mathrm{~mm})$ are completely altered to iddingsite both in the oxidized top and the bottom. Olivine content increases down the flow from 2 per cent to 5 per cent, and the largest phenocrysts occur close to the bottom (Core 12, Section 2, 136-141 cm).

Some short tabular plagioclase $\left(\mathrm{An}_{90-72}\right)$ microphenocrysts (up to $0.5 \mathrm{~mm}$ long) occur as glomeroporphyritic clusters and sometimes as single crystals. Plagioclase content is not over 1 to 1.5 per cent.

Very rare clinopyroxene $(<1 \%)$ occurs as small single microphenocrysts $(0.2-0.3 \mathrm{~mm})$.

The groundmass consists of plagioclase microlites $\left(\mathrm{An}_{72-55}\right)$, clinopyroxene, olivine, and opaque grains, with some clays after glass. In the flow top, the groundmass is represented by a nearly opaque dark brown substance and some small plagioclase microlites (up to $20 \%$ ) and clinopyroxene (up to 3 or $4 \%$ ). At a depth of 1.0 to 1.2 meters from the top, plagioclase microlites account for 60 to 65 per cent of the groundmass; clinopyroxene accounts for 20 to 25 per cent, olivine 5 per cent, opaque mineral 4 to 5 per cent, clays 5 to 6 per cent. Downward in the unit, despite the increase of plagioclase microlite sizes, the plagioclase content de- 
TABLE 2 - Continued

\begin{tabular}{|c|c|c|c|c|c|c|c|c|c|c|c|c|c|c|c|c|c|c|}
\hline \multicolumn{6}{|c|}{ Hole 432A, Flow Unit 3} & \multicolumn{4}{|c|}{ Hole 433C, Flow Unit 9} & \multicolumn{3}{|c|}{ Hole 433C, Flow Unit 11A } & \multicolumn{4}{|c|}{ Hole $433 \mathrm{C}$, Flow Unit 13} & \multicolumn{2}{|c|}{$\begin{array}{c}\text { Hole 433C, } \\
\text { Flow Unit 19B }\end{array}$} \\
\hline 13 & 14 & 15 & 16 & 17 & 18 & 30 & 31 & 32 & 33 & 35 & 36 & 37 & 41 & 42 & 43 & 44 & 47 & 48 \\
\hline 43.35 & 47.48 & 46.88 & 44.88 & 46.16 & 48.26 & 42.94 & 43.96 & 45.38 & 45.56 & 42.84 & 44.02 & 45.52 & 46.52 & 48.92 & 49.56 & 46.70 & 43.48 & 42.96 \\
\hline 3.40 & 3.10 & 3.10 & 3.17 & 3.00 & 3.10 & 2.28 & 2.60 & 2.45 & 2.37 & 2.45 & 3.00 & 2.90 & 2.75 & 2.70 & 2.60 & 2.82 & 1.82 & 1.32 \\
\hline 18.52 & 15.48 & 15.76 & 16.52 & 14.80 & 15.48 & 13.46 & 14.21 & 14.35 & 14.35 & 13.78 & 14.47 & 14.37 & 14.60 & 13.56 & 13.42 & 13.85 & 12.94 & 7.60 \\
\hline 14.59 & 5.42 & 5.36 & 10.02 & 5.00 & 5.15 & 12.78 & 8.49 & 5.90 & 5.10 & 14.82 & 8.78 & 8.24 & 8.44 & 3.54 & 2.23 & 7.84 & 8.51 & 1.73 \\
\hline 1.21 & 6.21 & 5.65 & 4.60 & 7.64 & 5.52 & 3.07 & 5.58 & 7.04 & 7.13 & 1.90 & 5.58 & 5.89 & 4.88 & 9.12 & 10.32 & 4.80 & 3.91 & 9.37 \\
\hline 0.20 & 0.16 & 0.20 & 0.23 & 0.20 & 0.12 & 0.07 & 0.11 & 0.07 & 0.11 & 0.16 & 0.09 & 0.11 & 0.12 & 0.17 & 0.19 & 0.15 & 0.14 & 0.14 \\
\hline 1.60 & 4.92 & 5.36 & 3.42 & 5.29 & 4.43 & 8.25 & 9.00 & 9.48 & 10.07 & 6.89 & 7.61 & 7.71 & 6.15 & 5.98 & 6.10 & 7.31 & 12.28 & 23.87 \\
\hline 2.90 & 9.21 & 9.43 & 5.87 & 8.91 & 7.95 & 4.15 & 8.09 & 8.99 & 8.30 & 5.52 & 7.61 & 8.30 & 9.28 & 11.36 & 11.25 & 8.46 & 2.59 & 5.12 \\
\hline 2.64 & 3.62 & 3.55 & 3.34 & 3.34 & 4.05 & 2.46 & 2.51 & 2.58 & 2.56 & 2.56 & 3.22 & 2.88 & 2.78 & 2.52 & 2.47 & 2.84 & 1.90 & 1.66 \\
\hline 2.23 & 1.30 & 1.20 & 1.47 & 1.16 & 1.73 & 1.64 & 0.69 & 0.30 & 0.33 & 1.23 & 0.76 & 0.61 & 1.09 & 0.48 & 0.44 & 0.98 & 0.74 & 1.24 \\
\hline 3.78 & 0.99 & 1.24 & 2.82 & $\begin{array}{l}1.62 \\
\text { n }\end{array}$ & 1.46 & 3.98 & 1.98 & 1.66 & 1.66 & $\begin{array}{l}4.89 \\
\text {. }\end{array}$ & 2.14 & 1.54 & 1.24 & 0.46 & 0.34 & 1.86 & 5.75 & 1.70 \\
\hline 4.50 & 1.27 & 1.52 & 3.10 & 1.88 & 1.42 & 4.26 & 2.15 & 1.80 & 1.92 & 2.41 & 2.36 & 1.15 & 1.48 & 0.64 & 0.33 & 1.86 & 5.70 & 3.17 \\
\hline 0.65 & 0.57 & 0.50 & 0.53 & 0.50 & 0.68 & 0.26 & 0.30 & 0.27 & 0.20 & 0.12 & 0.29 & 0.22 & 0.29 & 0.29 & 0.24 & 0.31 & 0.09 & 0.11 \\
\hline \multirow[t]{2}{*}{99.57} & 99.73 & 99.75 & 99.97 & 99.50 & 99.35 & 99.60 & 99.67 & 100.27 & 99.66 & 99.57 & 99.93 & 99.44 & 99.62 & 99.74 & 99.49 & 99.78 & 99.85 & 99.99 \\
\hline & & & & & & \multicolumn{4}{|c|}{ CIPW Norms } & & & & & & & & & \\
\hline 13.94 & - & - & 3.90 & - & - & 2.34 & - & - & - & 2.46 & - & 1.0 & 2.40 & 2.28 & 1.62 & 2 & 6.79 & - \\
\hline 14.47 & 7.79 & 7.23 & 9.46 & 7.23 & 10.57 & 10.57 & 4.45 & 1.67 & 2.23 & 7.79 & 4.45 & 3.90 & 6.68 & 2.78 & 2.78 & 6.12 & 5.01 & 7.79 \\
\hline 24.64 & 31.46 & 30.93 & 29.88 & 29.36 & 35.65 & 22.54 & 22.02 & 22.54 & 22.5 & 23.59 & 28.31 & 25.17 & 24.12 & 21.50 & 20.97 & 25.17 & 18.35 & 11.35 \\
\hline 11.13 & 22.81 & 24.20 & 27.26 & 22.81 & 19.47 & 20.58 & 26.70 & 27.54 & 27.81 & 24.20 & 24.20 & 25.31 & 25.03 & 24.75 & 24.48 & 22.81 & 13.63 & 10.01 \\
\hline - & - & - & - & - & - & - & - & - & - & - & - & - & - & - & - & - & - & 1.70 \\
\hline - & 8.59 & 8. & - & 8.1 & 6.9 & - & 5.57 & 6.9 & 5.4 & 2.21 & 5.57 & 6.3 & 8.59 & 12.54 & 12.54 & 7.90 & - & 6.62 \\
\hline - & 6.63 & 6 & - & 5. & 5.6 & - & 4.82 & & 4.1 & 1.91 & 4.82 & 5.52 & 7.43 & 7.33 & 6.52 & 6.83 & - & 4.82 \\
\hline - & 1.06 & & - & 2.11 & & - & - & 0.92 & 0 . & - & - & - & - & 4.75 & 5.67 & - & - & 1.19 \\
\hline 4.32 & 3.81 & 3.11 & 9.03 & 4. & 3 & 22.49 & 17.06 & 14.05 & 15.0 & 16.66 & 10.24 & 14.35 & 8.33 & 7.73 & 8.83 & 12.05 & 34.53 & - \\
\hline - & 0.66 & 0. & - & 1.71 & 0. & - & - & 2. & 3.6 & - & - & - & - & 5.14 & 7.65 & - & - & - \\
\hline- & 1.55 & 2. & - & 2.81 & 1. & - & 1.30 & 3. & 4. & - & 3.38 & - & - & - & -- & - & - & 40.38 \\
\hline - & 0.20 & 0 & - & 1.22 & & - & - & & & - & - & - & - & - & - & - & - & 10.39 \\
\hline - & 8.10 & 8. & 6.7. & 7.64 & 7. & 3.94 & 11.34 & & 7. & - & 9.96 & 11.34 & 8.33 & 5.09 & 3.42 & 8.10 & 8.57 & 2.55 \\
\hline 3.34 & 6.07 & 6. & 6.37 & 5.92 & 6. & 4.70 & 5.16 & 4.8 & 4.7 & 4.70 & 5.92 & 5.77 & 5.46 & 5.16 & 5.01 & 5.61 & 3.95 & 2.58 \\
\hline 1.68 & 1.35 & 1.35 & 1.35 & 1.35 & 1.68 & 0.67 & 0.67 & 0.67 & 0.67 & 0.34 & 0.67 & 0.67 & 0.67 & 0.67 & 0.67 & 0.67 & 0.34 & 0.34 \\
\hline 15.97 & - & - & 6.07 & - & - & 11.34 & 1.12 & - & - & 16.13 & 2.40 & 0.64 & 3.03 & - & - & 2.55 & 3.67 & - \\
\hline 20 & - & - & - & - & - & - & - & - & - & 0.16 & - & - & - & - & - & - & - & - \\
\hline 8.77 & - & - & - & - & - & 1.59 & - & - & - & - & - & - & - & - & - & - & 5.20 & - \\
\hline
\end{tabular}

TABLE 3

Chemical Analyses of Plagioclase from Flow Unit 1, Hole 433A

\begin{tabular}{l|rrr|rr}
\hline $\begin{array}{l}\text { Sampled } \\
\text { Interval }\end{array}$ & \multicolumn{3}{|c|}{$20-2,42-47 \mathrm{~cm}$} & \multicolumn{2}{|c}{$21-3,128-134 \mathrm{~cm}$} \\
\hline $\begin{array}{l}\text { Phenocryst } \\
\text { No. }\end{array}$ & \multicolumn{1}{|c|}{1} & \multicolumn{1}{c}{2} & \multicolumn{1}{c}{3} & \multicolumn{1}{c}{4} & \multicolumn{1}{c}{5} \\
\hline $\mathrm{SiO}_{2}$ & 48.80 & 49.51 & 49.56 & 49.12 & 49.57 \\
$\mathrm{TiO}_{2}$ & 0.06 & 0.06 & 0.07 & 0.07 & 0.07 \\
$\mathrm{Al}_{2} \mathrm{O}_{3}$ & 31.77 & 31.33 & 31.59 & 31.72 & 31.71 \\
$\mathrm{Fe}_{2} \mathrm{O}_{3}$ & 0.64 & 0.64 & 0.68 & 0.65 & 0.66 \\
$\mathrm{MgO}$ & 0.13 & 0.13 & 0.13 & 0.14 & 0.16 \\
$\mathrm{CaO}$ & 15.49 & 15.34 & 14.90 & 15.40 & 14.75 \\
$\mathrm{Na}_{2} \mathrm{O}$ & 3.44 & 3.40 & 3.54 & 3.34 & 3.42 \\
$\mathrm{~K}_{2} \mathrm{O}$ & 0.18 & 0.17 & 0.19 & 0.16 & 0.17 \\
$\mathrm{Total}$ & 100.51 & 100.58 & 100.66 & 100.60 & 100.51 \\
\hline
\end{tabular}

creases to 45 to 50 per cent (Core 12 , Section 3, 30-35 $\mathrm{cm}$ ) and increases again to 50 per cent in the bottom. On the contrary, the clinopyroxene content increases in the most crystallized part (35-40\% in Core 12 , Section 3, $30-35 \mathrm{~cm})$. The contents of the rest of the groundmass components are nearly the same throughout the flow. It is interesting that a zone of maximum sizes of groundmass minerals is situated at 0.5 meters from the flow bottom and, accordingly, at 3 meters from the top (Figure 7). Proceeding from Jaeger's (1961) calculation of the temperature distribution for cooling units, the zone of most long-term solidification for a 3.5-meter-thick flow must be located almost in the central part of the flow. The low position of the zone of maximum mineral sizes is probably explained by the fact that Flow Unit 9 overlaid Flow Unit 10 when the latter was not entirely cooled.

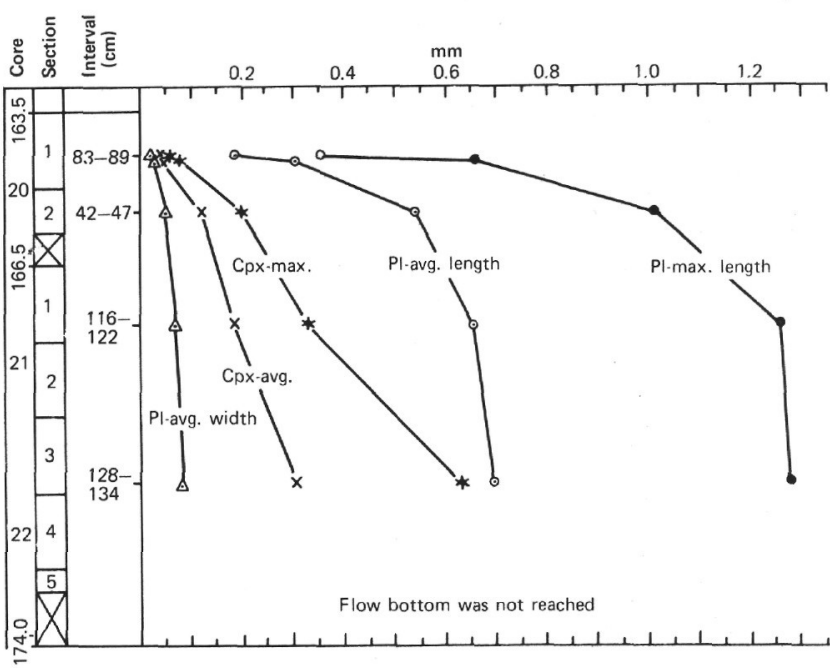

Figure 5. Size variation diagram of groundmass plagioclase and pyroxene grains throughout Flow 1, Hole $433 \mathrm{~A}$.

\section{Chemistry}

The results of whole-rock chemical analyses and variations of rock-forming oxides calculated for dry weight are presented in Table 2 and Figure 8, respectively. The oxidized zone occupies at least the upper half of the flow (see Figure 8) and the minimum $\mathrm{Fe}_{2} \mathrm{O}_{3} / \mathrm{FeO}$ ratio is registered in the bottom part. The minimum $\mathrm{K}_{2} \mathrm{O}$ content and $\mathrm{H}_{2} \mathrm{O}^{+}$content are also observed in the bottom part; $\mathrm{CaO}$ content decreases and total $\mathrm{Fe}$ as $\mathrm{Fe}_{2} \mathrm{O}_{3}$ increases with increasing degree of alteration, i.e., upward $\mathrm{Al}_{2} \mathrm{O}_{3}, \mathrm{TiO}_{2}$, and $\mathrm{Na}_{2} \mathrm{O}$ contents are most constant throughout the flow. 


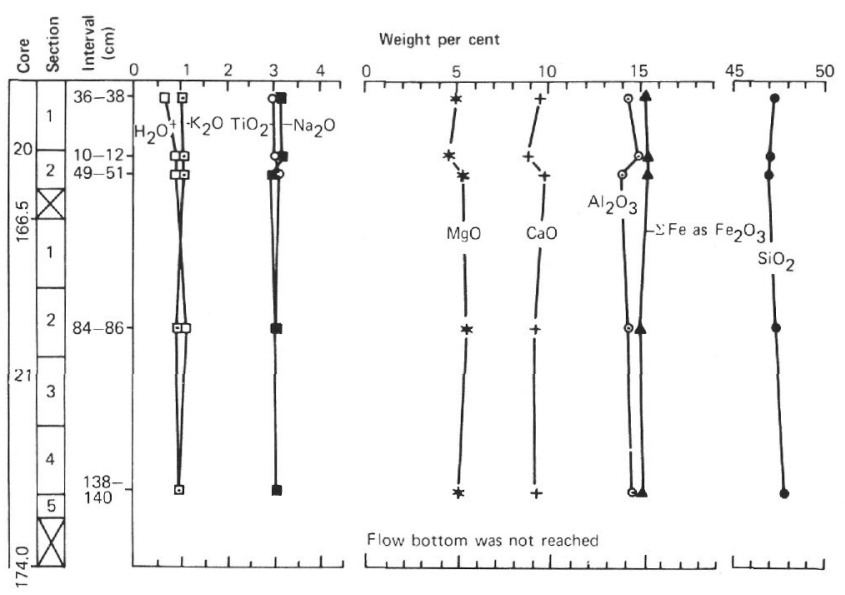

Figure 6. Variations of bulk chemistry throughout Flow 1, Hole $433 \mathrm{~A}$.

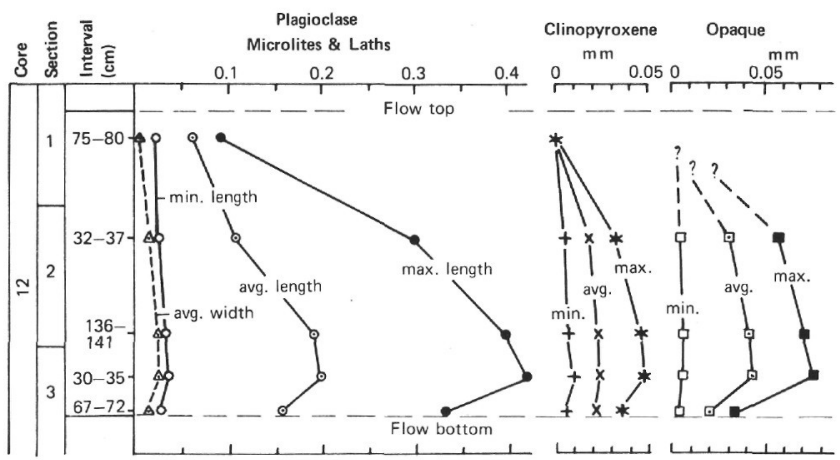

Figure 7. Size variation diagram of groundmass plagioclase, clinopyroxene, and opaque grains throughout Flow 9, Hole 433C.

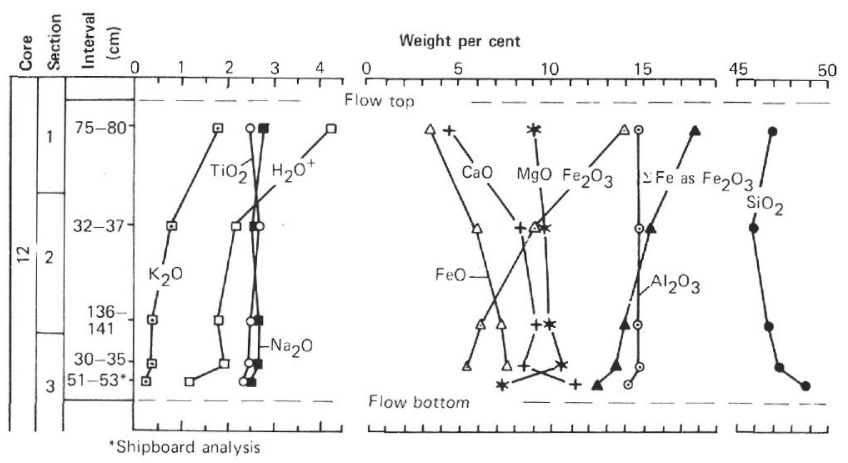

Figure 8. Variations of bulk chemistry throughout Flow 9, Hole 433C.

According to the classification of Macdonald and Katsura (1964), this flow is transitional between tholeiitic basalt and tholeiitic olivine basalt, since its chemical composition is tholeiitic, and it contains about 5 per cent of modal olivine in the most unaltered parts.

\section{FLOW UNIT 11A, HOLE 433C}

The flow is represented by sparsely phyric vesicular basalt transitional between tholeiitic and alkalic basalt. Its top and bottom can be distinctly defined, owing to oxidation and vesicle increase, both of which are more intensive in the top. The calculated thickness is about 7.5 meters and the core recovery was 4 meters. We took only three samples: in the flow top, 0.5 meters below the top, and in the flow interior (see Figure 9).

\section{Petrography}

Plagioclase (1-2.5\%), olivine (2-3\%), and clinopyroxene (1-3\%) occur as phenocrysts and microphenocrysts. Their contents increase slightly from the flow top to the interior. Plagioclase $\left(\mathrm{An}_{82-65}\right) 0.5$ to $1.5 \mathrm{~mm}$ long is partially altered to clays, especially in the flow top. Olivine phenocrysts $(1.0-1.5 \mathrm{~mm})$ are altered to iddingsite with clay cores; microphenocrysts $(0.3-1.0 \mathrm{~mm})$ are completely altered to iddingsite. Clinopyroxene (titanaugite) occurs as fresh microphenocrysts, 0.4 to $0.6 \mathrm{~mm}$, rarely to $1 \mathrm{~mm}$. The groundmass of the flow interior consists of plagioclase $\mathrm{An}_{68-48}(45-50 \%)$, clinopyroxene $(35 \%)$, olivine altered to iddingsite $(6-8 \%)$, opaque (4-6\%), clays after glass $(5-7 \%)$, and rare needles of apatite $(<1 \%)$. There are some interstitial feldspars with refractive index close to 1.54. The groundmass texture varies from vitrophyric in the flow top to intergranular in the central part of flow. Sizes of plagioclase microlites, clinopyroxene, and opaque grains increase to $0.48,0.06$ and $0.07 \mathrm{~mm}$, respectively, in the uppermost 0.5 meters, and in the deeper flow interior their sizes increase insignificantly, especially for plagioclase (Figure 9).

\section{Chemistry}

Figure 10 shows variations of chemical composition calculated for dry weight. In contrast to Flow 9, a clear zone of oxidation is typical only for the top, with $\mathrm{Fe}_{2} \mathrm{O}_{3}$ / $\mathrm{FeO}$ ratio reaching 7.8 , but at 0.5 meters from the top it

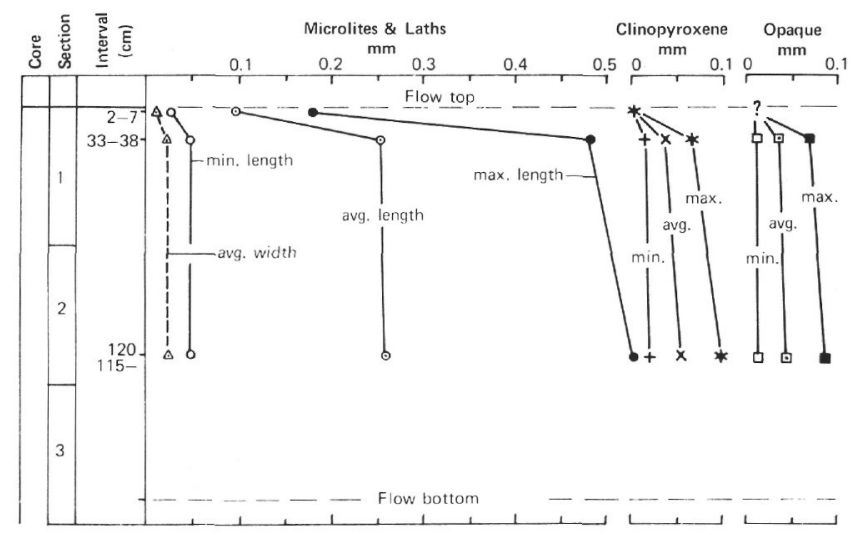

Figure 9. Size variation diagram of groundmass plagioclase, clinopyroxene, and opaque grains throughout Flow 11a, Hole 433C. 


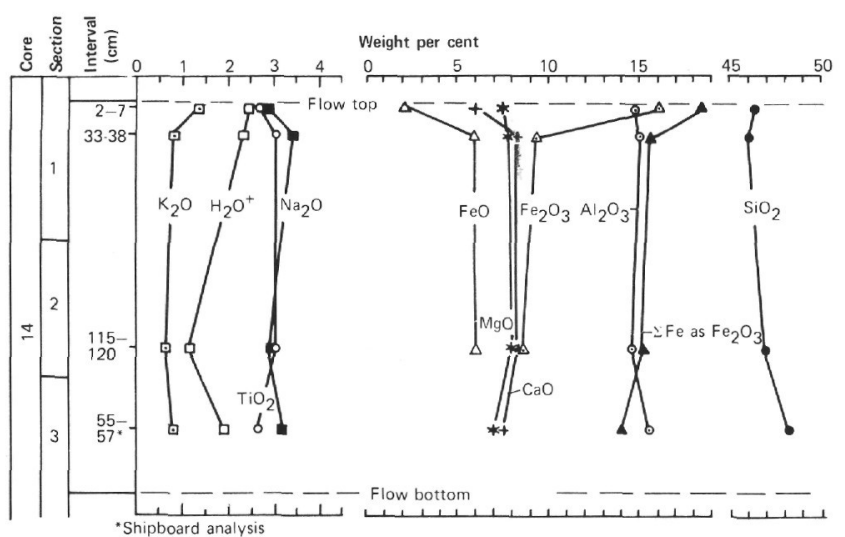

Figure 10. Variations of bulk chemistry throughout Flow 11a, Hole 433C.

decreases to 1.57 . Similarly to the previous flows, $\mathrm{CaO}$ and $\mathrm{MgO}$ contents decrease and $\mathrm{K}_{2} \mathrm{O}$ increases in the oxidized zone. In contrast to Flow 9, the oxidized top appears to have lower $\mathrm{Na}_{2} \mathrm{O}$ and $\mathrm{TiO}_{2}$ contents; but this may not actually be so, because of the increase of total iron and $\mathrm{K}_{2} \mathrm{O}$.

On the basis of contents of alkalis, this flow is referred to the alkalic basalt or is intermediate between the alkalic and tholeiitic series. We find it difficult to classify this basalt more precisely. Interstitial feldspar occurring in the groundmass also suggests that the flow belongs to the alkalic series.

\section{FLOW UNIT 13}

According to the cored interval, the flow thickness is 12.2 meters, but the core recovery does not exceed 4 meters. The locations of the samples studied are given in Figure 11.

\section{Petrography}

Sparsely phyric basalt of this flow consists of plagioclase phenocrysts (1-3\%) 0.5 to $2.0 \mathrm{~mm}$ long, augite $(<1 \%)$, single phenocrysts of olivine, found near the bottom, and groundmass.

The groundmass is composed of plagioclase, clinopyroxene, olivine, opaque mineral, and clays after glass. Sizes of groundmass plagioclase, clinopyroxene, and opaque grains, reflecting degree of crystallization, are shown in Figure 11. The glass content in the top and bottom samples (see Figure 11) is 8 to 10 per cent, decreasing to 1 to 3 per cent in the flow interior. The clinopyroxene coitent rises with degree of crystallization: from 10 percent at the top and bottom to 30 per cent in the flow interior. The groundmass plagioclase content, in contrast, decreases slightly from 60 to 65 per cent in Core 16, Section 1, 32-38 cm and Core 19, Section $1,48-54 \mathrm{~cm}$, to 50 to 55 per cent in the flow interior (Core 17, Section 1, 64-69 cm; see Figure 11). The groundmass texture changes from hyalopilitic to intergranular subtrachytic in the flow interior.

\section{Chemistry}

Table 2 and Figure 12 give the whole-rock chemical compositions for Flow 13. Except for vesicular and oxi-

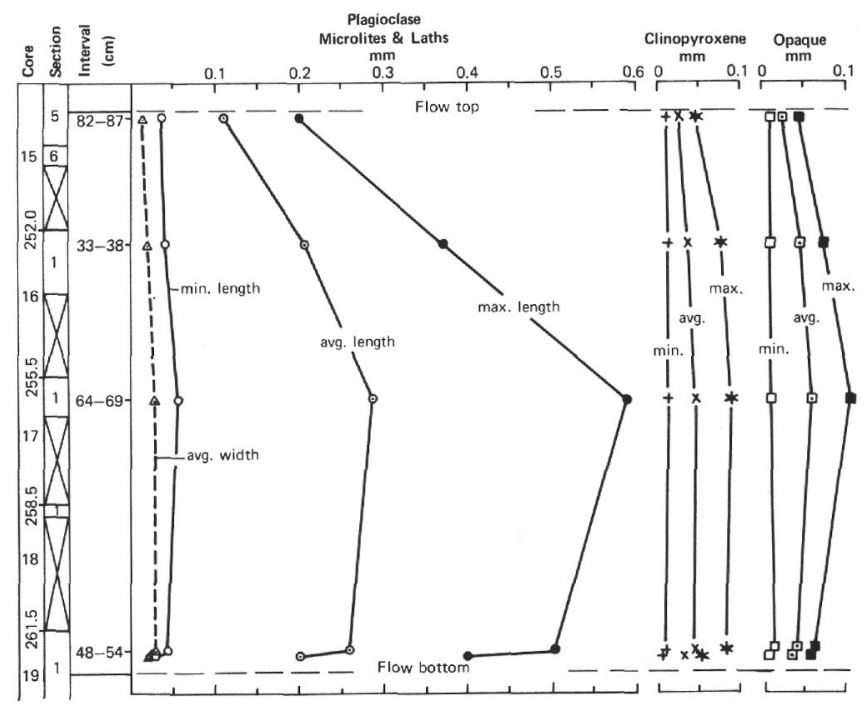

Figure 11. Size variation diagram of groundmass plagioclase, clinopyroxene, and opaque grains throughout Flow 13, Hole 433C.

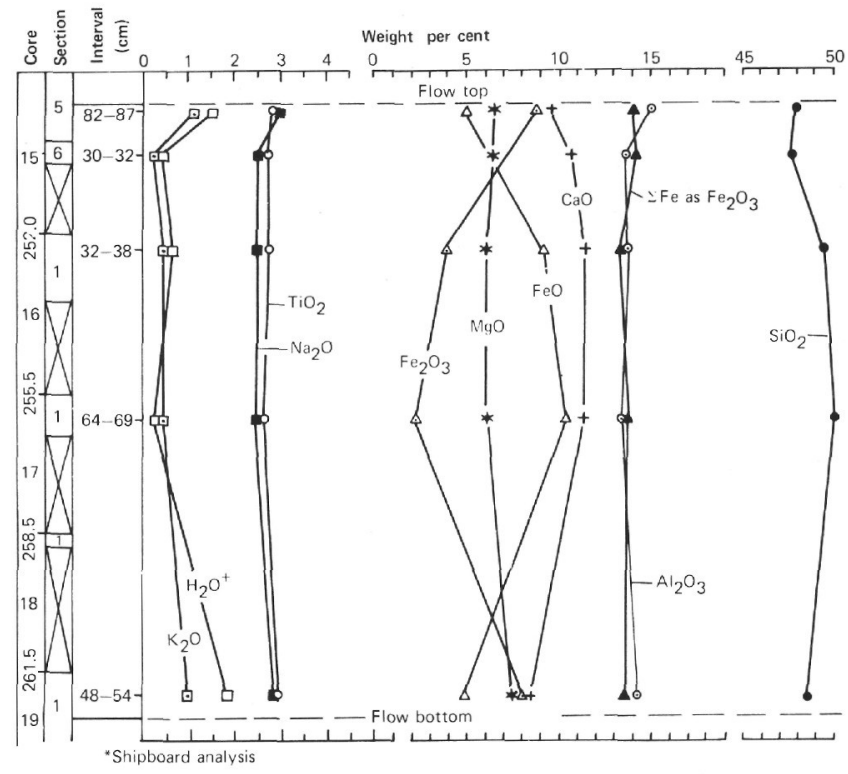

Figure 12. Variations of bulk chemistry throughout Flow 13, Hole 433C.

dized top and bottom, the concentrations of major elements are nearly the same throughout the flow. Variations in the top and bottom are first of all caused by oxidation, which results in the increase of the $\mathrm{Fe}_{2} \mathrm{O}_{3} / \mathrm{FeO}$ ratio from the interior (0.21) to the top (1.73) and bottom (1.63). $\mathrm{K}_{2} \mathrm{O}$ content also enlarges because of alteration. The change in $\mathrm{H}_{2} \mathrm{O}^{+}$content is a sensitive indicator of changes in $\mathrm{K}_{2} \mathrm{O}$. In the altered zones of the top and bottom, the $\mathrm{Na}_{2} \mathrm{O}$ content increases, but $\mathrm{CaO}$ and $\mathrm{MgO}$ contents decrease, in contrast to Flows 9 and 11A of the same hole.

The chemical composition of the flow is tholeiitic with norm quartz; it is oversaturated tholeiite, according to the classification of Yoder and Tilley (1962). The 
reference to a tholeiitic series is quite reliable, since alteration changes the chemical composition to the alkalic series, owing to increase of $\mathrm{K}_{2} \mathrm{O}$ and $\mathrm{Na}_{2} \mathrm{O}$ contents.

\section{FLOW UNIT 19B}

The 19.4-meter-thick flow of picrite-basalt with the full core recovery is interesting from the point of view of distinct olivine settling. But, having only two samples from the top and bottom at our disposal (Figure 13), we cannot characterize changes of mineral and chemical composition throughout the flow.

\section{Petrography}

The olivine phenocryst content is 25 to 30 per cent in the flow top, and reaches 55 to 60 per cent in the bottom. In the flow interior, olivine is fresh, with iddingsite rims. Table 4 illustrates the zoned character of olivine: its cores are more magnesian $\left(\mathrm{Fo}_{88}\right)$, in comparison with peripheral parts $\left(\mathrm{Fo}_{80}\right)$.

The groundmass is represented by plagioclase, clinopyroxene, olivine, opaque mineral, some clays, and zeolites.

\section{Chemistry}

The chemical variations throughout the flow (Figure 13) depend on two factors: olivine settling and altera-

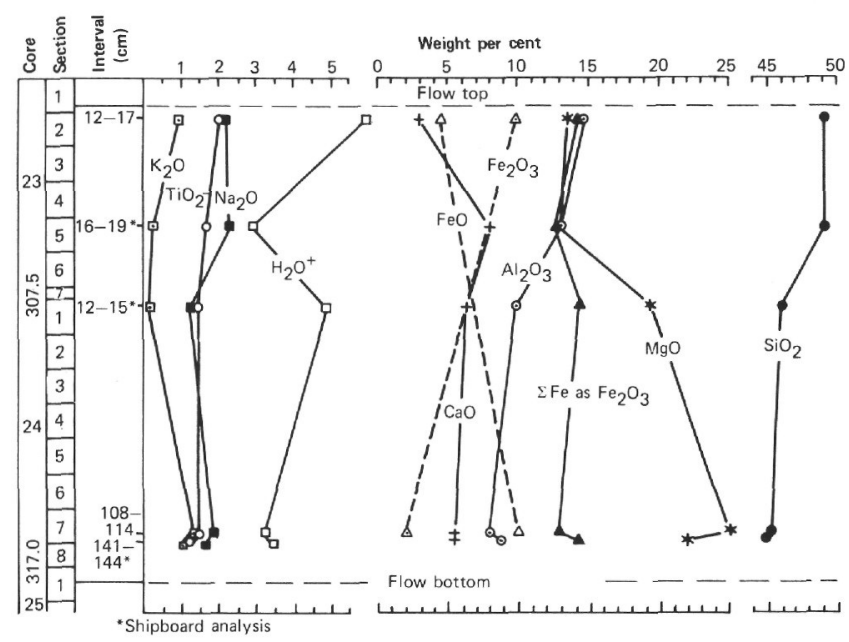

Figure 13. Variations of bulk chemistry throughout Flow 19b, Hole 433C.

TABLE 4

Chemical Analyses of Three Olivine Phenocrysts from Flow Unit 19B, Hole 433C

\begin{tabular}{|c|c|c|c|c|c|c|c|}
\hline & \multicolumn{7}{|c|}{ Core 24 , Section $7,108-114 \mathrm{~cm}$} \\
\hline & \multicolumn{3}{|c|}{1} & \multicolumn{2}{|c|}{2} & \multicolumn{2}{|c|}{3} \\
\hline & Core & Interm. & Margin & Core & Margin & Core & Core \\
\hline $\mathrm{SiO}_{2}$ & 41.13 & 40.79 & 40.17 & 41.49 & 39.89 & 41.64 & 41.00 \\
\hline $\mathrm{TiO}_{2}$ & 0.02 & 0.02 & 0.03 & 0.02 & 0.03 & 0.02 & 0.02 \\
\hline $\mathrm{Fe}_{2} \mathrm{O}_{3}$ & 11.89 & 13.10 & 18.46 & 12.98 & 16.96 & 12.17 & 12.20 \\
\hline $\mathrm{Cr}_{2} \mathrm{O}_{3}$ & 0.12 & 0.09 & 0.13 & 0.08 & 0.08 & 0.12 & 0.12 \\
\hline $\mathrm{MgO}$ & 46.13 & 45.85 & 41.76 & 45.21 & 42.53 & 45.95 & 46.15 \\
\hline $\mathrm{CaO}$ & 0.40 & 0.42 & 0.36 & 0.42 & 0.38 & 0.36 & 0.35 \\
\hline Total & 99.69 & 100.27 & 100.91 & 100.20 & 99.87 & 100.26 & 99.84 \\
\hline
\end{tabular}

tion. The increase in $\mathrm{MgO}$ content downward in the flow is the main chemical indicator of settling. On the basis of four chemical analyses (two made aboard ship), $\mathrm{MgO}$ content decreases first from top to bottom and then increases abruptly (see Figure 13); $\mathrm{SiO}_{2}, \mathrm{Al}_{2} \mathrm{O}_{3}$, and $\mathrm{CaO}$ contents have inverse correlation with $\mathrm{MgO}$ content. As a whole, $\mathrm{SiO}_{2}, \mathrm{Al}_{2} \mathrm{O}_{3}$ and $\mathrm{CaO}$ distribution throughout the flow is similar to that for the lava lake of Makaopuhi, Hawaii (Moore and Evans, 1967), and correlates with Fujii's (1974) theoretical curves for phenocryst settling.

The increase in $\mathrm{K}_{2} \mathrm{O}$ content, as in other flows, depends upon alterations. Oxidation of the flow top is clear from the $\mathrm{Fe}_{2} \mathrm{O}_{3} / \mathrm{FeO}$ ratio: in the fresher flow bottom and the most altered top it is 0.18 and 2.18 , respectively.

On the basis of its mineral and chemical compositions, the flow as a whole is typical oceanic picritebasalt, analogous to the same Hawaiian rocks.

\section{FLOW UNIT 25}

Sparsely phyric basalt of this 8.2-meter-thick flow (core recovery of $6 \mathrm{~m}$ ) has a distinct top and bottom. We took seven samples from throughout the flow (Figure 14) for detailed studies of the conditions of crystallization and alteration.

\section{Petrography}

Plagioclase (3-5\%), olivine (1-3\%), and clinopyroxene $(<1 \%)$ occur as phenocrysts and microphenocrysts. The composition of plagioclase phenocrysts $(0.5-2.5$ $\mathrm{mm}$ long) varies from $\mathrm{An}_{70}$ to $\mathrm{An}_{58}$ in the flow top and bottom and $\mathrm{An}_{88-60}$ in the flow interior. Olivine is represented by phenocrysts and microphenocrysts $(0.3-$ $1.5 \mathrm{~mm})$. It is interesting that the phenocrysts are euhedral and subhedral in the flow top and bottom and that their content is 2 to 3 per cent, whereas in the flow interior only anhedral microphenocrysts occur and their content is not more than 1 per cent. Short-prismatic clinopyroxene microphenocrysts $(0.3-0.5 \mathrm{~mm})$ are often formed as glomeroporphyritic clusters with plagioclase microphenocrysts.

The groundmass consists of plagioclase microlites, clinopyroxene, olivine, opaque grains, and some glass altered to clays. Figure 14 shows sizes of the main groundmass minerals. The zone of maximum sizes of plagioclase microlites is located in the near-bottom part (Core 28, Section 3, 136-142 cm), while that of clinopyroxene and of opaque minerals is in the central part of the flow.

Plagioclase, clinopyroxene, olivine, opaque, and clays after glass in the most crystallized flow interior account for 55 to 60,25 to $30,1,5$, and 8 to 10 per cent, respectively. It is noteworthy that the groundmass olivine content is somewhat higher (up to 3 or $4 \%$ ) in the top and bottom. This, along with the decrease of olivine phenocryst contents in the flow interior, is probably caused by olivine resorption characteristic of the rocks of the tholeiitic series. 


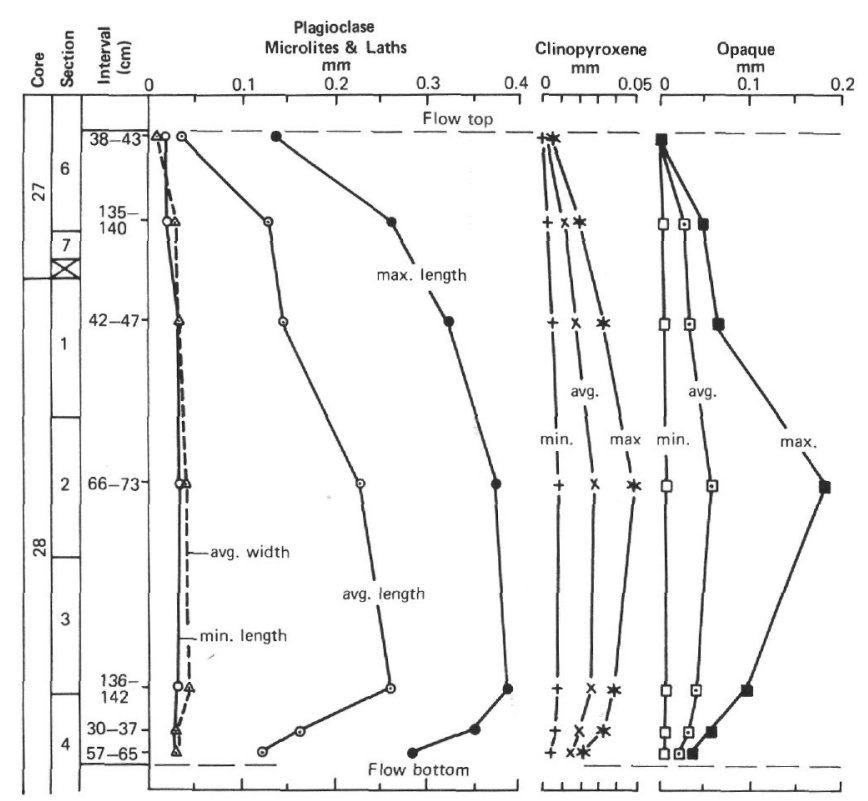

Figure 14. Size variation diagram of groundmass plagioclase, clinopyroxene, and opaque grains throughout Flow 25, Hole 433C.

\section{Chemistry}

The chemical composition of this flow (see Table 2 and Figure 15) depends primarily on secondary alteration of the top and bottom. These alterations are: $\mathrm{K}_{2} \mathrm{O}$, $\mathrm{H}_{2} \mathrm{O}^{+}$, and total $\mathrm{Fe}$ contents and $\mathrm{Fe}_{2} \mathrm{O}_{3} / \mathrm{FeO}$ ratio increase and $\mathrm{CaO}$ content decreases. There are no visible variations of $\mathrm{MgO}, \mathrm{SiO}_{2}$, or $\mathrm{TiO}_{2}$ contents throughout the flow. According to its mineral and chemical compositions, the flow is tholeiitic basalt with some norm olivine or norm quartz.

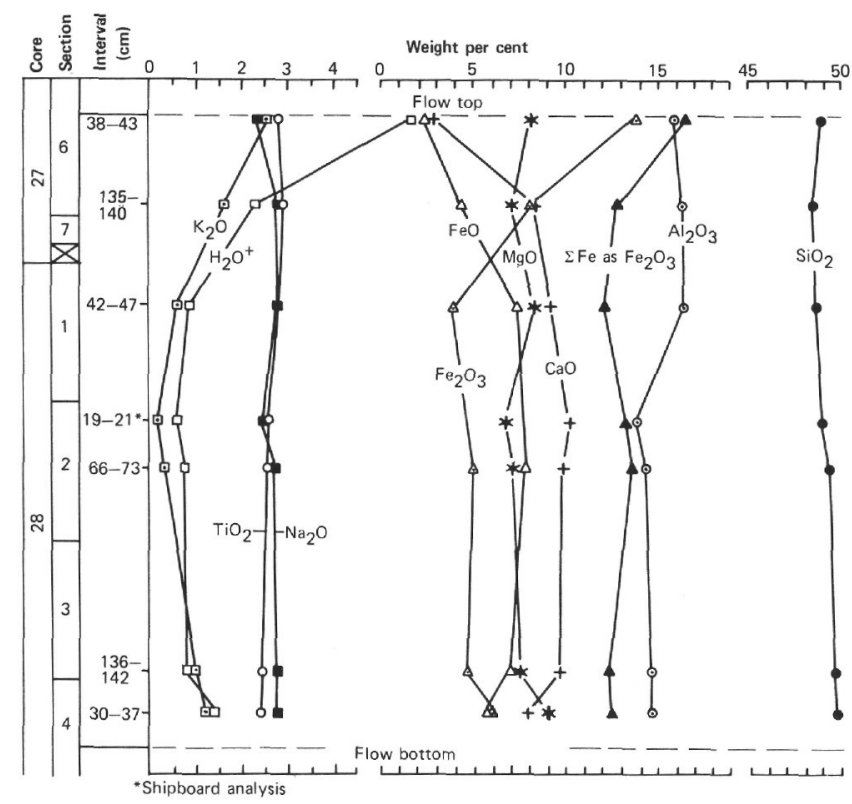

Figure 15. Variations of bulk chemistry throughout Flow 25, Hole 433C.

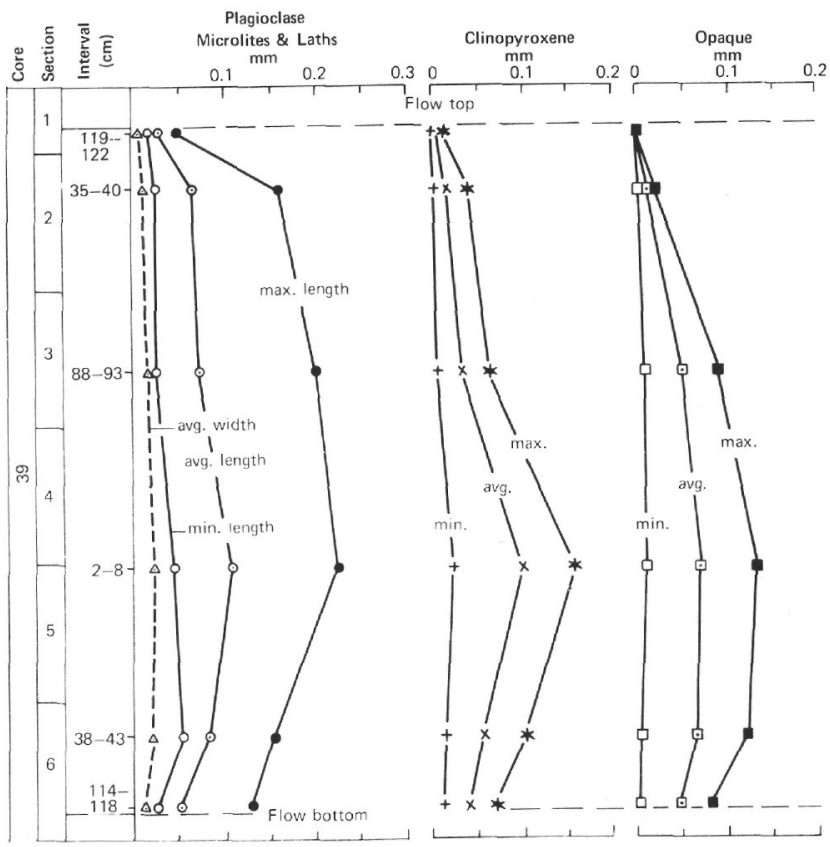

Figure 16. Size variation diagram of groundmass plagioclase, clinopyroxene, and opaque grains throughout Flow 48, Hole 433C.

\section{FLOW UNIT 48}

The flow is composed of sparsely olivine phyric basalt some 7 meters thick at the full core recovery. The top and bottom are clearly distinguished in terms of oxidation and vesicles increase from 3-5 per cent in the flow interior to 25-30 per cent in the top and 10-12 per cent in the bottom. Six intervals were sampled to characterize the flow (Figure 16).

\section{Petrography}

Olivine $(0.3-2.0 \mathrm{~mm})$, completely altered to clays and iddingsite, is practically the only phenocryst mineral. Results of the detailed calculation of the olivine phenocryst content of the flow are given in Table 5. This distribution corresponds to the theoretical settling curve in sills (Fujii, 1974).

The groundmass consists of plagioclase microlites, pyroxene, olivine, opaque grains, and clays after glass. Sizes of the groundmass major minerals are shown in Figure 16. The most crystallized lower part of the flow contains 50 to 55 per cent plagioclase, 30 to 35 per cent clinopyroxene, 7 to 10 per cent opaques, 2 to 3 per cent

TABLE 5

Phenocryst Contents, Flow Unit 48

\begin{tabular}{l|l|l}
\hline Sampled Interval & \multicolumn{1}{|c|}{ Position } & Contents (vol. \%) \\
\hline $39-1,119-122 \mathrm{~cm}$ & top, chilled part & 4 \\
$39-2,35-40$ & 0.6 m from top & 2.9 \\
$39-3,88-93$ & 2.7 m from top & 3.9 \\
$39-5,2-8$ & 4.7 m from top, & 5.36 \\
& 2.3 m from bottom & \\
$39-6,38-43$ & 0.8 m from bottom & 5.94 \\
$39-6,114-118$ & bottom & 4 \\
\hline
\end{tabular}


olivine, and 3 to 4 per cent glass. The content of grains of groundmass olivine increases generally outward at the top and bottom - up to 7 or 8 per cent. This fact, together with the anhedral shape of olivine phenocrysts, testifies to resorption, typical of the rocks of the tholeiitic series.

\section{Chemistry}

The major-element contents (see Table 2 and Figure 17) are approximately the same throughout the flow. The flow is tholeiitic basalt. The olivine content increasing toward the bottom, determined from mineral composition, does not correlate with $\mathrm{MgO}$ content. Alterations of the flow top and bottom are analogous to those of the flows described earlier; for instance, of Flow 25. Normative olivine occurs in the most unaltered parts, and oxidation leads to the appearance of quartz.

\section{FLOW UNIT 54}

Aphyric basalt of this flow is 7.5 meters thick. The top and bottom are rather distinct owing to the oxidized zones and increased vesicularity. Four samples were taken to characterize this flow (Figure 18).

\section{Petrography}

Single phenocrysts of plagioclase (up to $1.5 \mathrm{~mm}$ long) and titanaugite (up to $1 \mathrm{~mm}$ ) occur. Plagioclase is zoned $\mathrm{An}_{74-58}$ in the flow top and bottom and $\mathrm{An}_{88-54}$ in the flow interior. Single microphenocrysts of olivine occur in the bottom.

The groundmass of the most crystallized flow interior located in the near-bottom part (see Figure 18) is composed of plagioclase microlites $(45-50 \%)$, pyroxene $(30-35 \%)$, olivine $(1-2 \%)$, opaque grains $(3-4 \%)$, and

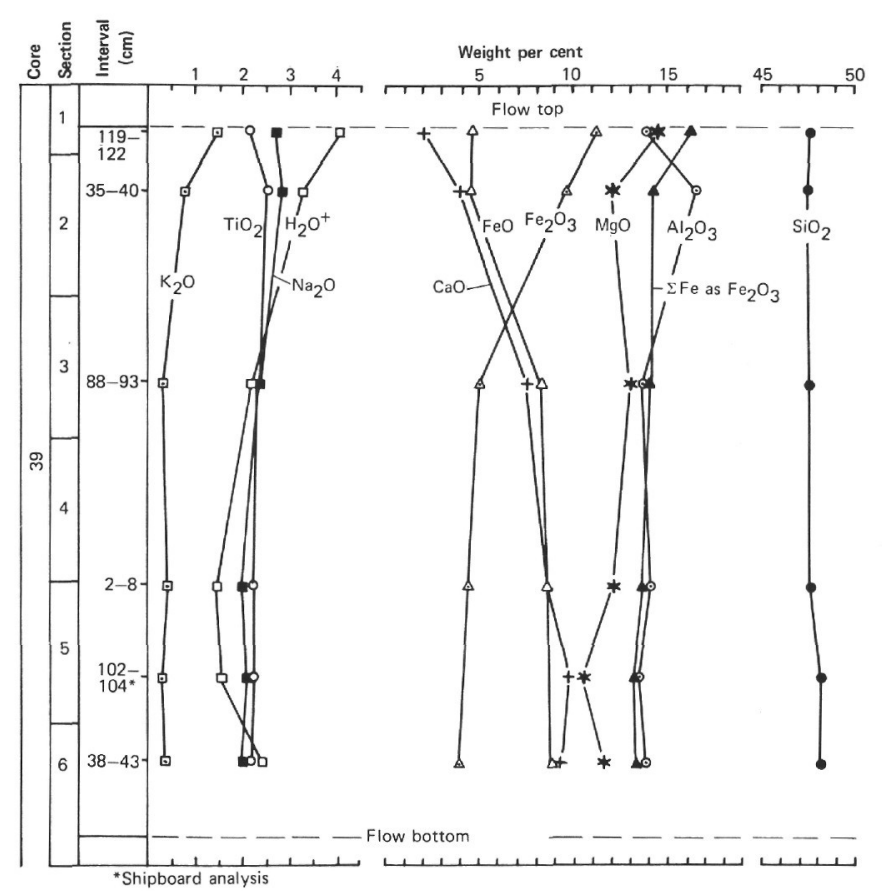

Figure 17. Variations of bulk chemistry throughout Flow 48, Hole 433C.

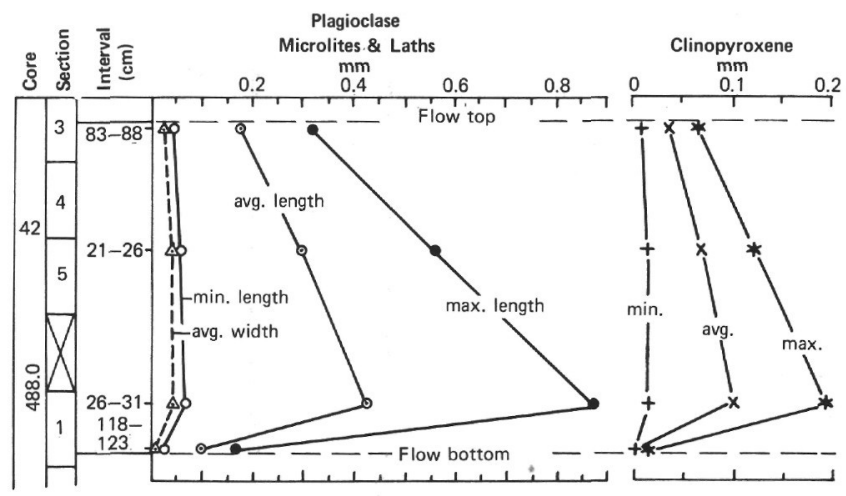

Figure 18. Size variation diagram of groundmass plagioclase and clinopyroxene grains throughout Flow 54, Hole 433C.

glass altered to clays $(10 \%)$. The quantity and size of olivine grains increase toward both the top and bottom. This, together with olivine microphenocrysts, present only in the top and bottom, may indicate olivine resorption typical of the rocks of the tholeiitic series.

\section{Chemistry}

The major-element contents are nearly the same in three samples from the flow interior (see Table 2 and Figure 19). The flow is tholeiitic basalt, according to its mineral and chemical composition. Variations in composition of the top and bottom are caused by alteration analogous to that of the flows described earlier.

\section{FLOW UNIT 60}

Aphyric-sparsely phyric basalt of this flow is 4.6 meters thick, and has a distinct top and bottom. Seven samples were taken from throughout the flow to characterize peculiarities of crystallization and variations of chemical composition dependent upon alteration of rocks (Figure 20).

\section{Petrography}

The total contents of phenocrysts of olivine, plagioclase, and clinopyroxene do not exceed 2 per cent. Plagioclase phenocrysts (to $2.5 \mathrm{~mm}$ ) are fresh throughout

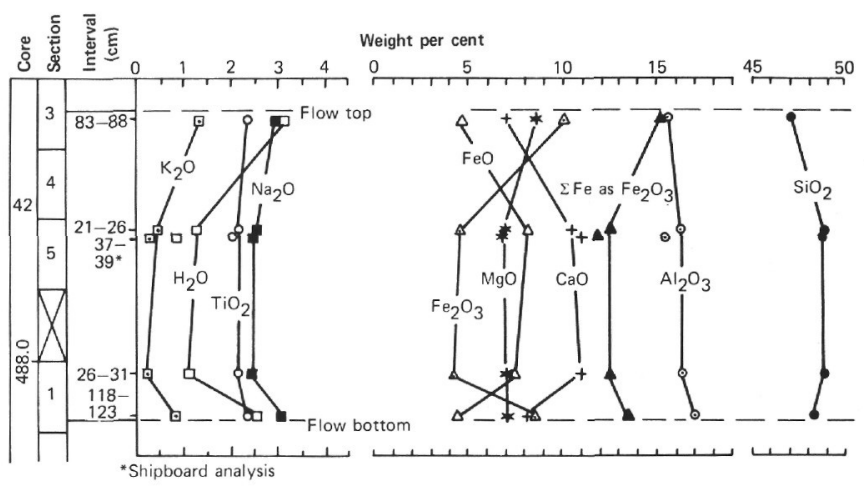

Figure 19. Variations of bulk chemistry throughout Flow 54, Hole 433C. 


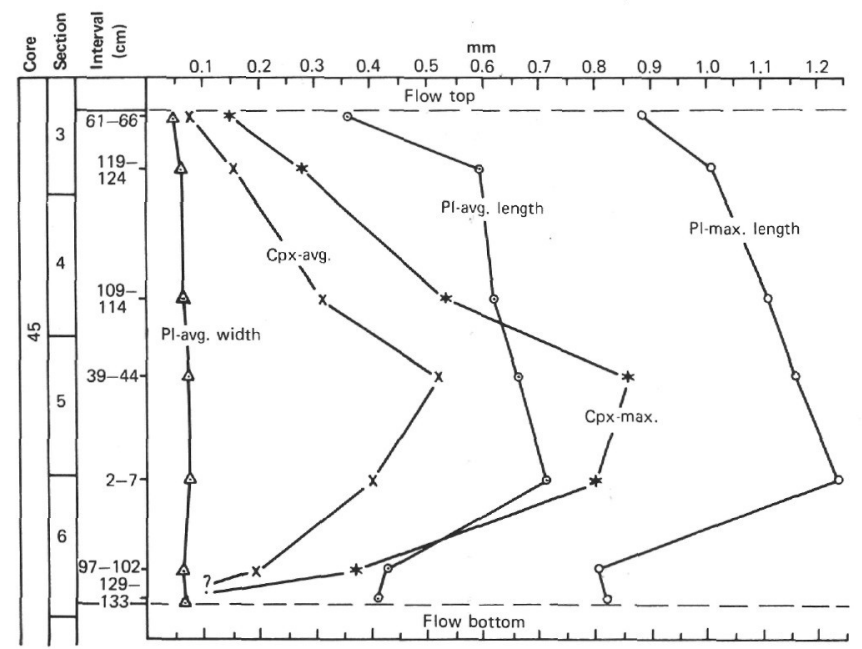

Figure 20. Size variation diagram of groundmass plagioclase and clinopyroxene grains throughout Flow 60, Hole 433C.

the flow, except for slight alteration to clays in cleavages in the top and bottom. Single clinopyroxene phenocrysts are also fresh, and olivine phenocrysts are altered to iddingsite with some clays.

The groundmass of the flow interior consists of plagioclase microlites and laths (45-50\%), clinopyroxene $(30-35 \%)$, opaque grains $(5-7 \%)$, iddingsite after olivine $(1-2 \%)$, and clays after glass (8-10\%). Clinopyroxene content decreases to between 5 and 7 per cent, and glass (clay) content increases up to 40 per cent in the flow top and bottom. The degree of groundmass crystallization is clear in Figure 20. It is worth noting that the zone of maximum clinopyroxene sizes is located higher in the flow than that of plagioclase. Large clinopyroxene grains in the groundmass have sub-ophitic texture. Rare olivine grains are the result of phenocryst resorption rather than of growth after the flow outpouring.

\section{Chemistry}

The major-element contents (see Table 2 and Figure 21) vary because of alteration like that of the previously described flows of tholeiitic basalts.

\section{DISCUSSION}

\section{Classification}

All the lavas studied have been altered to some extent, and their initial mineral and chemical compositions are not always distinct. Still, a comparison of the mineralogy and whole-rock chemistry of the fresh flow interiors with moderately and badly altered flow tops and bottoms permits us to classify the flows using the alkali: silica diagram (Figures 22 and 23) of Macdonald and Katsura (1964). As the alteration leads mainly to the increase of $\mathrm{K}_{2} \mathrm{O}$ content, rocks falling below the tholeiitic-alkalic line are really tholeiitic (see Figure 22), and rocks falling over the line may be alkalic or tholeiitic. Figure 22 shows clearly that the most altered flow parts of tholeiitic basalts fall into the field of the alkalic

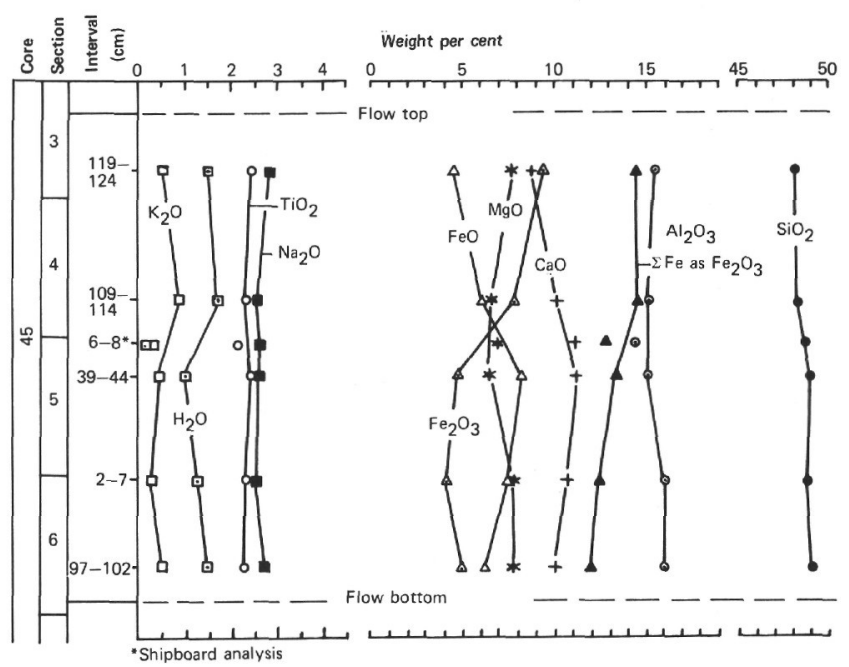

Figure 21. Variations of bulk chemistry throughout Flow 60, Hole 433C.

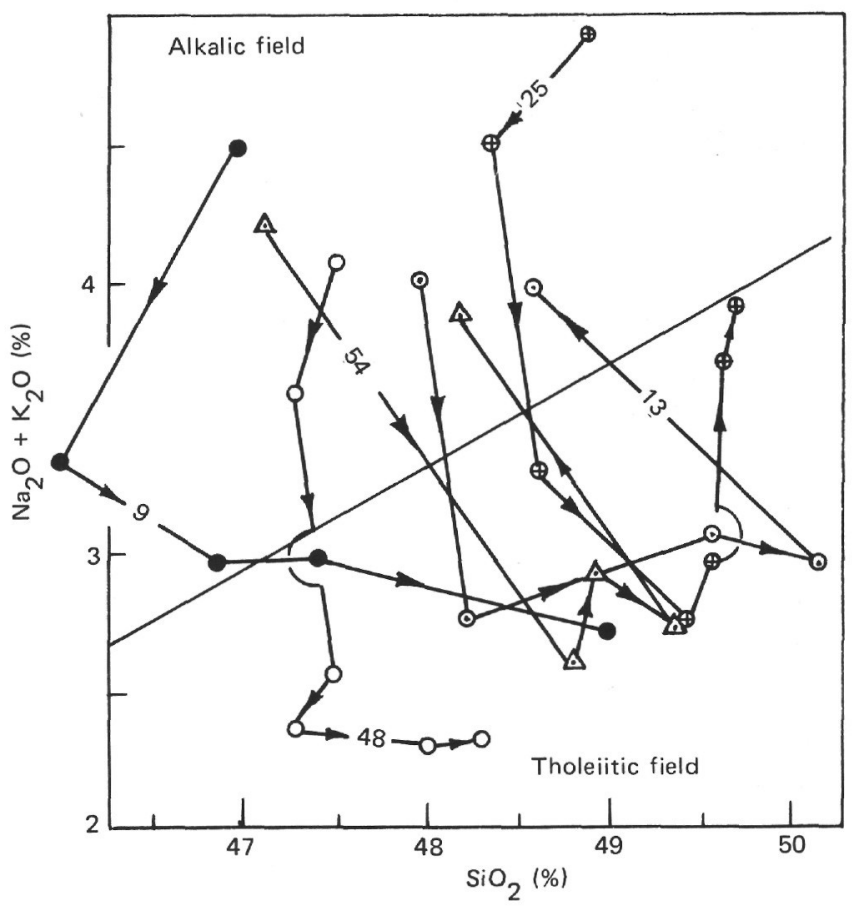

Figure 22. $\mathrm{SiO}_{2}$ versus $\mathrm{Na}_{2} \mathrm{O}+\mathrm{K}_{2} \mathrm{O}$ diagram for five tholeiitic flows, Hole 433C. Thick line divides fields of alkalic and tholeiitic basalts (after Macdonald and Katsura, 1964). Points of the same flow are connected with thin lines; arrows show the direction from top to bottom.

series. The presence of interstitial feldspar with refractive index close to 1.54 is typical of flows of the alkalic series.

The transitional Flow Unit 11A reveals the same tendency to alkali decrease in the most unaltered flow part. Although all the analyses of this flow fall into the alkalic field, the reference of the flow to the alkalic series may raise doubts because of the high content of com- 


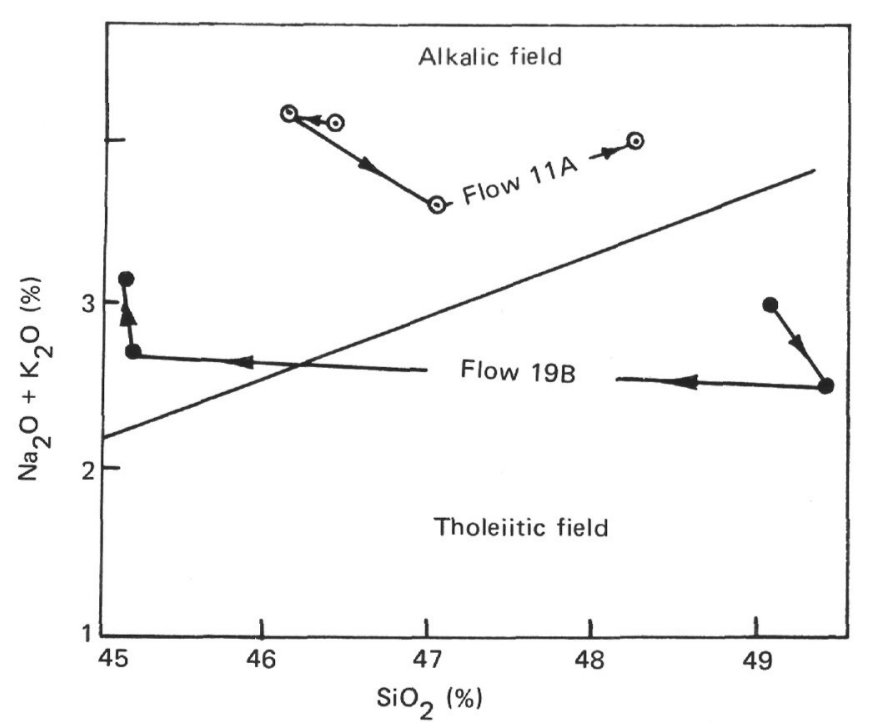

Figure 23. $\mathrm{SiO}_{2}$ versus $\mathrm{Na}_{2} \mathrm{O}+\mathrm{K}_{2} \mathrm{O}$ diagrams for Flow Units $11 a$ and $19 b$, Hole 433C. Conventional signs are the same as in Figure 22.

bined water. Nevertheless, the reference of this flow to alkalic basalt is favored because interstitial feldspar occurs in the groundmass.

\section{Alteration}

Two types of alteration take place in the lava flows of the Emperor Seamounts, namely oxidation and the processes of palagonitization and halmyrolysis. The first one is expressed chemically in a sharp increase of the $\mathrm{Fe}_{2} \mathrm{O}_{3} / \mathrm{FeO}$ ratio up to 14 in the oxidized zones of the tops and bottoms of the flows; in the fresher flow interiors this ratio is usually lower than 1 .

The high degree of oxidation is typical only for weathering above sea level. Laterite between Flow Units 2 and 3, Hole 432A, is a final product of such weathering under continental tropical and subtropical conditions. Apart from oxidation, lateritic weathering is characterized by washing out of $\mathrm{SiO}_{2}, \mathrm{CaO}$, and $\mathrm{MgO}$ and proportional increases of the other components. Oxidation is expressed mineralogically in alteration of magnetite and ilmenite to hematite and limonite and alteration of olivine to hematite and iddingsite.

The second type of weathering is manifested chemically in the increase of $\mathrm{K}_{2} \mathrm{O}$ and combined water contents, which correlate directly between themselves (Figure 24). This type of alteration is characterized by filling of vesicles and fractures with clays and by alteration of olivine and glass to clays.

The X-ray diffraction analyses were performed for clays from Flow Units 4A, 5, 48, and 54. Samples were processed under three conditions: air-dry, saturated with glycerine, and annealed at $550^{\circ} \mathrm{C}(2 \mathrm{~g})$. According to terminology accepted by most researchers, the clays under study belong to the smectite group. Minerals have properties indicative of this group; i.e., they swell in glycerine $\left(d_{(001)}=18 \AA\right)$ and "squeeze" during annealing $\left(d_{(001)}=9.5-9.8 \AA\right)$. Approximately identical $d_{(001)}=11.7$ $-12.5 \AA$ in the air-dry state is common for all the

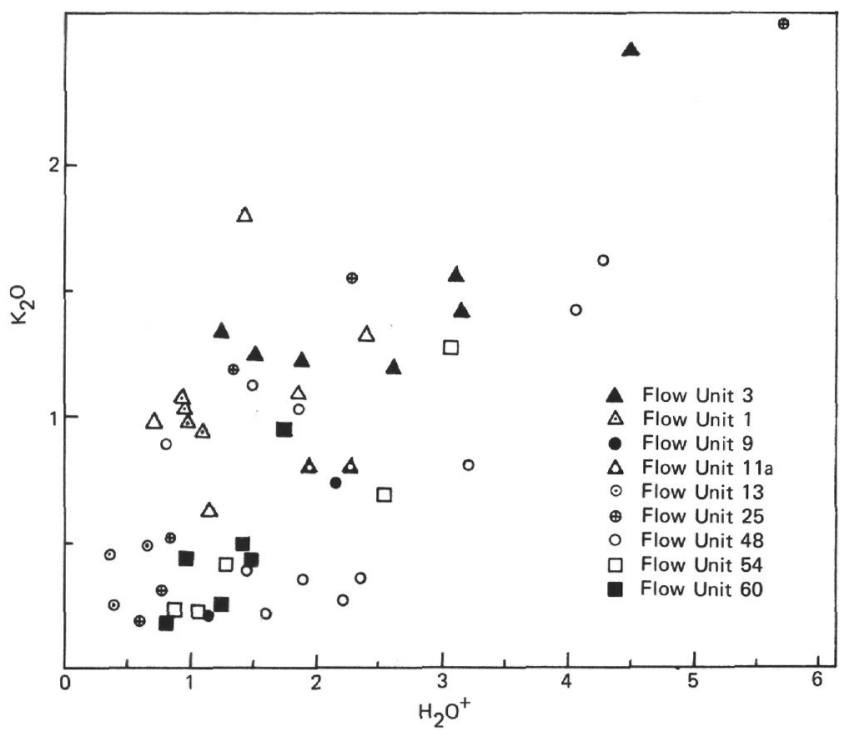

Figure 24. $\mathrm{H}_{2} \mathrm{O}+$ versus $\mathrm{K}_{2} \mathrm{O}$ diagram for some flows of Holes 432A, 433A, and 433C.

samples, indicating cation exchange taking place in interbeds of $\mathrm{K}$ and $\mathrm{Na}$ types.

Two types of clay minerals occur in the samples studied. Minerals from Flow Units 4A, 5, 48 and from vesicles of Flow Unit 54 are trioctahedral smectite, i.e., saponite. They are more crystallized (in the saturated state they have up to five orders of reflection) than clays from vesicles of Flow Unit 5 and from small fractures of Flow Unit 54. The last two samples are represented by a mixture of di- and trioctahedral smectites. This is supported by two indicators, $d_{060}=1.53 \AA$ (trioctahedral smectite) and $d_{060}=1.49 \AA$ (dioctahedral smectite). All other samples have $d_{060}=1.53 \AA$ only.

The formation of clay minerals occurred apparently under marine conditions. This process is analogous to palagonitization when the increase in $\mathrm{K}_{2} \mathrm{O}$ and decrease in $\mathrm{Na}_{2} \mathrm{O}$ and $\mathrm{CaO}$ contents take place (Moore, 1966). Because clay minerals of submarine weathering are formed principally after glass and fill vesicles and fractures, bottoms and especially tops of flows undergo the most intense alterations, just as during oxidation.

\section{Crystallization of Groundmass}

The volume of fraction crystallized and the sizes and number of groundmass crystals are major indicators of lava flow crystallization after its outpouring. All the flows studied, except for chilled top and bottom parts, are characterized by a high fraction crystallized, generally over 90 per cent. As crystal sizes at high degree of crystallization are universely correlated to their number, we measured grain sizes but did not calculate their number. For plagioclase we measured length and width. Surely, the size of grains perpendicular to $(010)$ is the most demonstrative value in studying kinetics of plagioclase crystal growth (Kirkpatrick, 1977). We suppose that in studying the processes of crystallization of silicate melts and formation of rocks the more informative value is the plagioclase length. Grains impinge on one 
another during crystallization, and this causes slowing down and cessation of crystal growth.

On the basis of variations in the length of plagioclase microlites, two lava flow types can be distinguished: (1) flows with a distinct zone of maximum length of plagioclase grains, located in the most prolonged cooling interiors; (2) flows with plagioclase microlites increasing in size at some distance from chilled zones of tops and bottoms and of almost the same sizes in the interiors.

All the tholeiitic flows studied belong to the first type. Flows with small thickness are most common, e.g., Flow Units 9 and 54 (see Figures 7 and 18). Small clinopyroxene grains, compared with plagioclase grains, are typical, except for Flow Units 48 and 60 (Figure 25).

The thick flows of alkalic basalts belong to the second flow type. For instance, in Flow 3, Hole 432A, more than 16 meters thick, the plagioclase increases in length up to $0.5 \mathrm{~mm}$ from the bottom to a depth of about 4 meters, and deeper it remains almost the same and even decreases slightly, although the size of clinopyroxene grains increases (see Figure 3 ).

In Flow 1, Hole 433A, more than 11.5 meters thick, the plagioclase size reaches $1.26 \mathrm{~mm}$ at a depth of about 4 meters, and deeper it is almost the same (see Figure 3). This tendency is also seen in Flow Unit 11A: plagioclase reaches $0.48 \mathrm{~mm}$ at a depth of about 0.5 meters, and deeper - up to 4 meters - it reaches only $0.53 \mathrm{~mm}$ (see Figure 9).

The difference between these two types is first of all caused by the rate of cooling, i.e., magnitude of undercooling, which in turn depends on the flow thickness. The chemical composition of melt is also of importance: the thickness of Flow Unit 11A is about 7.5 meters i.e., like that of most tholeiitic flows studied - but the flow is closer to the second type.
Theoretical considerations, computer simulation, and experimental data on nucleation and growth of plagioclase and pyroxene indicate that the rates of both nucleation and growth should be higher at higher undercooling (Kirkpatrick, 1976, 1977; Kirkpatrick et al. 1976). In lava flows, undercooling decreases toward the flow interiors, and the rates of nucleation and growth decrease respectively. At almost complete crystallization, typical of the flows studied, the rate of nucleation is responsible for the length of plagioclase microlites, since the grains impinge on one another, causing slowing down and cessation of crystal growth. Besides, rates of nucleation increase with increasing undercooling much more rapidly than rates of crystal growth (Kirkpatrick, 1977).

In the interiors of thick flows, undercooling seems to be small and almost constant; this is supported by constant rates of the $1065^{\circ}$ geotherm (the base of the crust in Alae lava lake was defined by Peck et al., 1966) advance in Kilauea lava lakes, Hawaii (Kirkpatrick, 1977). Therefore, the maximum size of plagioclase crystals is nearly constant in the interiors of thick flows. A slight decrease in plagioclase length in the parts of most prolonged cooling in Flow Unit 3, Hole 432A, may have been caused by clinopyroxene, which starts to crystallize at the higher temperature (Peck et al., 1966; Moore and Evans, 1967). Clinopyroxene grains that appeared before plagioclase impinge on it, and this makes plagioclase grow much slower.

Two type of diagrams, namely, size of groundmass minerals versus depth (Figures 3, 5, 7, 9, 11, 14, 16, 18, and 20) and the groundmass plagioclase length versus size of clinopyroxene (Figure 25), show that in the top and bottom, under conditions of high undercooling, plagioclase dominates and clinopyroxene occurs as nu-
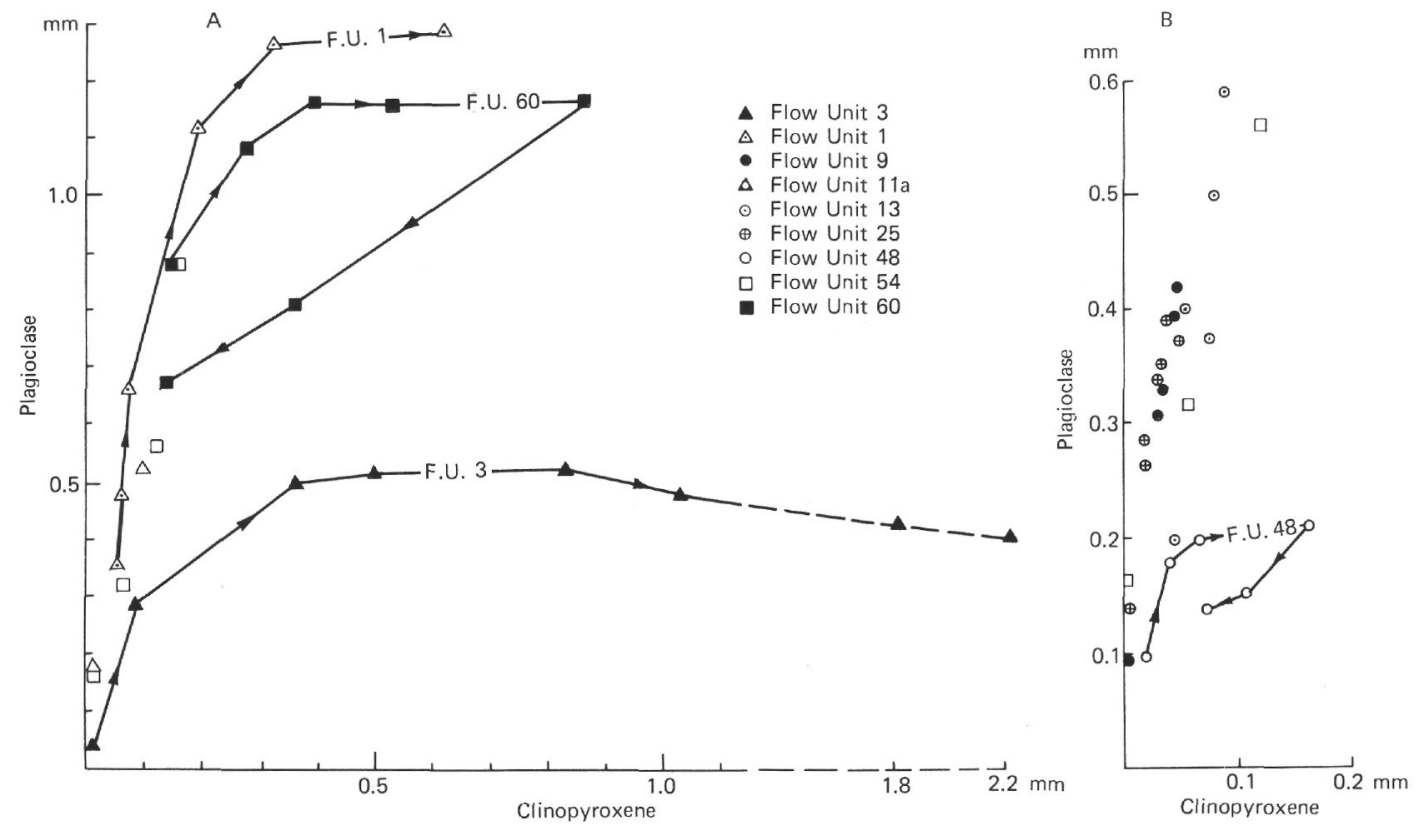

Figure 25. Diagrams showing the size of clinopyroxene grains versus site of plagioclase grains in groundmass of the flow units studied. 
cleus and very small grains. The size and modal composition (volume \%) of clinopyroxene increase with the decrease of undercooling; i.e., they are greater in the most slowly cooling flow interiors. The increase of clinopyroxene size is mostly caused by the growing of ophitic crystals.

It is noticeable that, in Flow Units 48 and 60 , at a given size of plagioclase, clinopyroxene is larger in the lower parts of flows, in comparison with the upper ones (see Figure 25). Therefore, the size of the groundmass plagioclase of these flows is close to the maximum (limited), as in the flows of the second type.

Despite the small thickness $(4.6 \mathrm{~m})$ of Flow Unit 60, the groundmass mineral sizes are anomalously large (see Figure 20). Even in the flow top, plagioclase length reaches $0.87 \mathrm{~mm}$ and clinopyroxene is $0.15 \mathrm{~mm}$ at nearly complete crystallization. This indicates that crystallization proceeds for a long time. Perhaps Flow Unit 60 is a lava flow in a lava tube. These lava tubes are common to pahoehoe flows (Macdonald and Abbott, 1972).

The regularities revealed are the basis for studying the process of melt crystallization in a flow after its pouring out onto the surface. On the whole, they agree with theoretical inferences (Kirkpatrick, 1975, 1976) and studies of crystal growth in the Hawaiian lava lakes (Kirkpatrick, 1977) and lava flows of the 1975-1976 Fissure Tolbachik eruption (Ponomarev et al., 1979). Distinct correlation between the chemical composition of the groundmass minerals and phenocryst-free composition is needed for further studies of the regularities of groundmass crystallization in lava flows.

\section{REFERENCES}

Beeson, M. H., 1976. Petrology, mineralogy, and geochemistry of the East Molokai Volcanic Series, Hawaii, U.S. Geol. Surv. Prof. Paper 961, 53 pp.

Fujii, T., 1974. Crystal settling in a sill, Lithos, v. 7, pp. 133-137.
Jaeger, J. C., 1961. The cooling of irregularly shaped igneous bodies, Amer. Jour. Sci., v. 2\$9, pp. 721-734.

Kirkpatrick, R. J., 1975. Crystal growth from the melt: A review, Am. Mineralogist, v. 60, pp. 798-814.

, 1976. Towards a kinetic model for magma crystallization, Jour. Geophys. Research, v. 81, pp. 2565-2571. 1977. Nucleation and growth of plagioclase, Makaopuhi and Alae lava lakes, Kilauea Volcano, Hawaii, Geol. Soc. America Bull., v. 88, pp. 78-84.

Kirkpatrick, R. J., Robinson, G. R., and Hays, J. F., 1976. Kinetics of crystal growth from silicate melts: anorthite and diopside, Jour. Geophys. Research, v. 81, pp. 5715-5720.

Macdonald, G. A., 1968. Composition and origin of Hawaiian lavas, Geol. Soc. America Memoir 116, pp. 477-522. 1972. Composite lava flows on Haleakala Volcano, Hawaii, Geol. Soc. America Bull., v. 83, pp. 2971-2974.

Macdonald, G. A. and Abbott, A. T., 1970. Volcanoes in The Sea. The Geology of Hawaii. Honolulu (University of Hawaii Press), 441 pp.

Macdonald, G. A. and Katsura, T., 1964. Chemical composition of Hawaiian lavas, Jour. Petrology, v. 5, pp. 82-133.

Moore, J. G., 1966. Rate of palagonitization of submarine basalt adjacent to Hawaii, U.S. Geol. Survey Prof. Paper 550D, pp. 0163-0171.

Moore, J. G. and Evans, B. W., 1967. The role of olivine in the crystallization of the prehistoric Makaopuhi tholeiitic lava lake, Hawaii, Contr. Mineral. and Petrol., v. 15, pp. 202-223.

Peck, D. L., Wright, T. L., and Moore, J. G., 1966. Crystallization of tholeiitic basalt in Alae lava lake, Hawaii, Bull. Volcanol., v. 29, pp. 629-656.

Ponomarev, G. P., Sapozhinikov, E. A., and Brodskaya, R. L., 1979. Crystallization of microlitic phase in lavas of the South Tolbachik eruption, Bull. Volcanic Stations, v. 56 (in Russian).

Vande-Kirkov, J. V., 1974. A new version of diagram for determining intermediate and basic plagioclases at Fedorov universal stage, Bull. Volcanic Stations, v. 50, pp. 130-132 (in Russian).

Yoder, H. S. and Tilley, C. E., 1962. Origin of basalt magmas: An experimental study of natural and synthetic rock systems, Jour. Petrology, v. 3, pp. 342-532. 